IZA DP No. 5546

Free vs. Restricted Immigration:

Bilateral Country Study

Assaf Razin

Jackline Wahba

March 2011

Forschungsinstitut zur Zukunft der Arbeit Institute for the Study of Labor 


\title{
Free vs. Restricted Immigration: Bilateral Country Study
}

\author{
Assaf Razin \\ Tel Aviv University, Cornell University, \\ CEPR, NBER and IZA \\ Jackline Wahba \\ University of Southampton \\ and IZA

\section{Discussion Paper No. 5546 \\ March 2011} \\ IZA \\ P.O. Box 7240 \\ 53072 Bonn \\ Germany \\ Phone: +49-228-3894-0 \\ Fax: +49-228-3894-180 \\ E-mail: iza@iza.org
}

\begin{abstract}
Any opinions expressed here are those of the author(s) and not those of IZA. Research published in this series may include views on policy, but the institute itself takes no institutional policy positions.

The Institute for the Study of Labor (IZA) in Bonn is a local and virtual international research center and a place of communication between science, politics and business. IZA is an independent nonprofit organization supported by Deutsche Post Foundation. The center is associated with the University of Bonn and offers a stimulating research environment through its international network, workshops and conferences, data service, project support, research visits and doctoral program. IZA engages in (i) original and internationally competitive research in all fields of labor economics, (ii) development of policy concepts, and (iii) dissemination of research results and concepts to the interested public.
\end{abstract}

IZA Discussion Papers often represent preliminary work and are circulated to encourage discussion. Citation of such a paper should account for its provisional character. A revised version may be available directly from the author. 
IZA Discussion Paper No. 5546

March 2011

\section{ABSTRACT \\ Free vs. Restricted Immigration: Bilateral Country Study}

This paper tests the differential effects of the generosity of the welfare state under free migration and under policy-controlled migration, distinguishing between source developing and developed countries. We utilize free-movement within the EU to examine the free migration regime and compare that to immigration into the EU from two other groups, developed and developing source countries, to capture immigration-restricted regimes. We standardize cross-country education quality differences by using the Hanushek-Woessmann (2009) cognitive skills measure. We find strong support for the "magnet hypothesis" under the free-migration regime, and the "fiscal burden hypothesis" under the immigration-restricted regime even after controlling for differences in returns to skills in source and host countries.

JEL Classification: J61, J48

Keywords: migration, welfare state, EU

Corresponding author:

Jackie Wahba

School of Social Sciences

University of Southampton

Southampton

SO17 1BJ

United Kingdom

E-mail: J.Wahba@soton.ac.uk 
IZA Discussion Paper No. 5546

March 2011

\section{NON-TECHNICAL SUMMARY}

We test how the generosity of the welfare state affects the skill composition of immigrants across migration regimes. We utilize free-movement within the EU (old core) to examine the free migration regime and compare that to immigration into the EU from two other groups to capture immigration-restricted regime. We distinguish between immigration from developed versus developing source countries.

We find evidence that the generosity of the welfare state adversely affects the skillcomposition of immigrants under free-migration; but it exerts a more positive effect under a policy-controlled migration regime relative to a free-migration regime even after controlling for the differential returns in skills in source and host countries. Interestingly, these results hold for both developed and developing countries, but the effect tends to be larger for developed countries. In other words, immigrants from rich countries care more about the welfare state relative to those from poorer developing countries. However once we adjust for educational quality, the effect of welfare-state generosity on skill composition increases for immigration from developing countries and converges to that experienced by immigration from developed countries.

It is clear from our analysis that immigration policies favoring high-skilled migrants need to take into account educational quality. Hence, a selective immigration scheme based on years of education solely will not be as effective in identifying the high skilled as a points-based system where ability (for example, language ability and labor market experience) are considered.

Another important implication of our findings is that under free-migration, the generosity of the welfare state acts as a magnet for the unskilled. This suggests that harmonizing the minimum welfare provision within the EU may be an attractive option to reduce the negative effect of the welfare state on the skill composition of immigrants under free-migration. 


\section{Introduction}

Public debate on immigration has increasingly focused on the welfare state amid concerns that immigrants are a fiscal burden as recipients of the generous welfare state. There has also been growing literature on how welfare-state generosity works as a magnet to migrants. However, the effect of welfare programs on immigration and its composition depends crucially on the policy regime, namely whether migration is free or restricted. In other words, the generosity of the welfare state may affect the skill composition of immigrants differently, depending on the immigration policy adopted. This paper tests how the generosity of the welfare state affects the skill composition of the immigrants across these policy regimes.

In a free-migration regime, a typical welfare state with relatively abundant capital and high total factor productivity (implying relatively high wages for all skill levels) attracts both unskilled and skilled migrants. On the other hand, the generosity of the welfare state attracts unskilled (poor) migrants, as they expect to gain more from the benefits of the welfare state than what they expect to pay in taxes for these benefits: that is, they are net beneficiaries of the generous welfare state. In contrast, potential skilled (rich) migrants are deterred by the generosity of the welfare state. Thus the generosity of the welfare state shifts the migrant skill composition towards the unskilled. In the restricted-migration regime, these same considerations lead voters to open the door wide to skilled migration and slam the door shut on unskilled migration. Voters are motivated by two considerations: how migration affects their wages, and how it bears on the finances of the welfare state. Typically, 
unskilled migration depresses the unskilled wage and boosts the skilled wage. The opposite occurs with skilled migration. The effect of migration on the finances of the welfare state is common to all voters of all skills, because skilled migrants are net contributors to the welfare state, whereas unskilled migrants are net beneficiaries. From a public finance point of view, nativeborn voters of all skills would therefore opt for the skilled to come and for the unskilled to stay away to mitigate the fiscal burden.

We use core EU countries (old member states) to study empirically the policy-regime differential effect of the generosity of the welfare state on the skill composition of migration. Freedom of movement and the ability to reside and work anywhere within the EU are two of the fundamental rights which EU member states have must recognise. In contrast, labor mobility into EU member states from non-EU states is still restricted to various degrees by national policies. ${ }^{1}$ The paper utilizes this difference in policy regimes in EU and non-EU states to test the key differences between free- and policyrestricted migration, in conjunction with the effect of the welfare state on the skill composition of immigrants.

The paper, which follows from Cohen and Razin (2009), addresses the

\footnotetext{
${ }^{1}$ Despite the legal provision for the free movement of labor among the EU-15 (the old member countries), the level of cross-border labor mobility is low. Reasons cited for this include the existence of legal and administrative barriers, the lack of familiarity with other European languages, moving costs, inefficient housing markets, the limited portability of pension rights, problems with the international recognition of professional qualifications and the lack of transparency of job openings. The expansion of the EU to 25 member states in May 2004, was accompanied by concerns over the possibility of a wave of migration particularly of the low-skilled - from the ten new member states to the EU-15.
} 
effect of the generosity of the welfare state on the skill composition of immigrants. The paper makes three contributions. First, since welfare benefits might be one factor affecting the composition of migrants, we control for other potential factors that are likely to affect the selectivity of migration. As Borjas (1987) argues the characteristics of those who emigrate from a particular country will depend on that country's wage distribution. In poor countries, where the returns to skills are relatively high, there will be a "negative selection" of immigrants; whilst in rich countries, where returns to skills are relatively low, there will be "positive selection" of immigrants. Thus we control for both returns to skills in the source country measured by income inequality, as well as for the wage-premium skill differential in the host country. Second, the paper considers immigration from developing source countries as well as developed ones, since the impact of the generosity of the welfare state on the immigrant skill composition across these policy regimes may be different for (poor) developing countries compared to those from richer developed ones. We consider here a larger sample of source countries, which includes a sample of developing countries in addition to non-EU OECD countries. We employ bilateral data from the year 2000 on 16 EU countries (14 out of the EU-15 together with Norway and Switzerland, which benefit from free labor mobility bilateral agreements with the EU), 10 nonEU OECD countries, and 23 developing countries. ${ }^{2}$ Third, because a proper measure of immigrant skill is key to our analysis, we correct for educational quality, an issue which has been ignored in the empirical migration literature. In this way we attempt to obtain a relatively homogeneous classification of

\footnotetext{
${ }^{2}$ Our sample of source countries is dictated by data availability on educational quality.
} 
skill levels using the Hanushek-Woesmann (2009) measure of cognitive skills. We form source-host pairs of countries in which only the EU countries (plus Norway and Switzerland) serve as host countries, whereas all the countries in the sample serve as source countries. We decompose the source-host pairs into three groups: a "free-migration" group (source-host pairs within the EU, plus Norway and Switzerland), a "policy-controlled" group of developed countries (source-host pairs in which the host countries are the same as in the former group, and the source countries are from non-EU OECD countries), and a "policy-controlled" group of developing countries (source-host pairs in which the host countries are the same as in the former groups, and the source countries are from LDC countries). The free-restricted migration decomposition has its origin in the integration process in Europe that started in the 1950s, and is thus exogenous to the stock of migrants in the EU states in 2000 .

We also control for the potential endogeneity problem : the skill composition of migration itself may influence the voters' attitude towards the generosity of the welfare state. Recalling that skilled migrants are typically net contributors to the welfare state, whereas unskilled migrants are net beneficiaries, voters in the host country are likely to boost its welfare system when absorbing high-skill migration and curtail it when absorbing low-skill migration.

The rest of the paper is structured as follows. Section two provides an overview of the existing literature paying particular attention to the general welfare aspects of migration and the interaction between migration and the welfare state. Section three presents the data sources and discusses the 
schooling quality measure. Section four presents the econometric model and compares the findings for LDC source countries relative to DC source countries. Section five concludes.

\section{Empirical Evidence on Welfare Migration}

Existing literature brings out rich, though mixed, evidence on welfare migration. Several studies examine whether welfare-state generosity acts as a magnet for migrants; see Brueckner (2000) for a detailed review. A few studies focusing on the US, show that high-benefit states have more welfare-recipient migrants than the low-benefit regions, for example, Southwick (1981) and Gramlich and Laren (1984). Particular groups seem also to be drawn more by benefits than others. For example, Blank (1988) shows that welfare benefits have a significant positive effect on the location choice of female-headed households. Similarly, Enchautegui (1997) finds a positive effect of welfare benefits on the migration decision of women with young children. McKinnish (2005, 2007) also finds evidence of welfare migration, especially for those who are located close to state borders (where migration costs are lower). Meyer (2000) employs a conditional logit model, as well as a comparison-group method, to analyze the 1980 and 1990 US Census data and finds significant welfare-induced migration, particularly for high school dropouts. Borjas (1999) finds that low-skilled migrants are much more heavily clustered in high-benefit states, in comparison to other migrants or natives. On the other hand, Gelbach (2004) finds strong evidence of welfare migration in 1980, but less in 1990, whilst Walker (1994) uses the 1990 US Census data and finds 
no compelling evidence in support of the welfare magnet theory. Using data for 1979-92, Levine and Zimmerman (1999), show that welfare benefits have little effect on the probability of female-headed households (the recipients of the benefits) to relocate.

Empirical studies on the evidence of welfare migration in Europe and OECD countries also provide mixed conclusions. Khoudouz-Castezas (2004) studies emigration from 19th century Europe. He finds that the social insurance legislation, adopted by Bismarck in the 1880s, reduced the incentives of risk averse Germans to emigrate. He estimates that in the absence of social insurance, the German emigration rate from 1886 to 1913 would have been more than double its actual level. Peridy (2006) studies migration rates in 18 OECD host countries from 67 source countries and finds that the host-source ratio of welfare-state benefits (as measured by total public spending) has a significant positive effect on migration. De Giorgi and Pellizzari (2006) conduct an empirical investigation of migration from outside the EU-15. They find that welfare-state benefits attract migrants. When interacted with the education level, welfare benefits also show a positive effect on the probability of the lowest group of educated to immigrate; whereas the probabilities of the secondary and tertiary education groups are not significantly affected. Docquier et al. (2006) study the determinants of migration stocks in the OECD countries in the year 2000, with migrants from 184 countries, classified according to three education levels. They find that the social welfare programs encourage the migration of both skilled and unskilled workers. However, the unskilled are motivated by social expenditure much more than the skilled migrants. Thus they conclude that the skill composition of migrants is ad- 
versely affected by welfare-state benefits, that is, welfare benefits encourage migration biased towards the unskilled.

Unlike the above studies, our focus in this paper is about the effect of the welfare state on the composition of immigrants. Hence, it is paramount to control for the migration regime (free versus controlled) in order to obtain unbiased estimates of the generosity of the welfare state on migration (and on its skill composition). Studies of migration between states within the US, which are clearly confined to a single migration regime (namely, free migration), can help only in providing evidence of a free-migration regime. On the other hand, studies that employ samples confined to the policy-controlled migration regime, but at the same time employ a model of the migrants' choice whether to migrate and to which country, are evidently problematic. In this case, the estimates convey little information about the migrants' choices (and hence on the welfare state as a magnet to unskilled migrants), but rather on the migration policy choices of the host country. Finally, studies that refer to both migration regimes without controlling for them are problematic because they do not disentangle migration policies in the host countries, and the individual migrant's migration choices in the source countries.

\section{Empirical Analysis}

Our aim is to test how the generosity of the welfare state affects the skill composition of immigrants across policy regimes for both developing and developed source countries after controlling for returns to skills in source and host countries. It is common to focus on developed countries (OECD 
countries) where skill levels (usually proxied by education attainment) are comparable given the potential heterogeneity in education quality across developed and developing countries. We do not confine ourselves to developed countries in this paper but include a sample of developing countries for which we are able to control for the quality of education as described below.

In order to identify the difference in the welfare-state benefits effect on the skill composition of immigrants across migration regimes, the decomposition of the sample into group A, and groups B and C should be exogenous to the dependent variable- the skill composition of migrants. We argue that this is indeed the case for EU countries.

\subsection{Data}

We decompose our sample into three groups as follows. Group A contains only the source-host pairs of countries which allow free mobility of labor between them, according to the single-market treaty. Any kind of discrimination between native-born and immigrants, regarding labor market accessibility and welfare-state benefits eligibility is illegal. These are $16 \mathrm{Eu}-$

ropean countries: Austria, Belgium, Denmark, Finland, France, Germany, Greece, Ireland, Italy, Netherlands, Portugal, Spain, Sweden, UK, Norway and Switzerland.

Group B includes only the developed source-host pairs of countries within which the source country residents cannot freely move, work and receive social benefits in any of the host countries. The source countries, however, are ten developed countries: US, Canada, Japan, Australia, New Zealand, Israel, Taiwan, Hong Kong, Korea and Singapore. 
Group C includes the developing source-host pairs of countries in which the source country residents cannot freely move, work and receive social benefits in any of the host countries. Twenty three developing countries are included: Argentina, Brazil, Chile China, Colombia, Ecuador, Egypt, Jordan, India, Indonesia, Iran, Malaysia, Mexico, Morocco, Lebanon, Nigeria, Peru, Philippines, Tunisia, South Africa, Thailand, Turkey and Venezuela. In both groups $\mathrm{B}$ and $\mathrm{C}$, the host countries are the same EU countries as in group A. We distinguish between LDC and DC source countries and run separate regressions in order to compare the effect of the welfare state in both cases. The determinants of emigration and the effects of the generosity of the welfare state are likely to be different for poor developing countries relative to richer, developed ones:- e.g., the gap between the host and source countries in terms of wages, amenities, social spending and welfare are largers for developing countries.

The analysis uses bilateral migration data from Docquier and Marfouk (2006). The data contain bilateral immigrant stocks, based on census and register data, for the years 1990 and 2000. Immigrants of a working age (25+) are defined as foreign-born. The immigrants are classified into three education levels: low-skilled (0-8 schooling years), medium-skilled (9-12 schooling years) and high-skilled (13+ schooling years). The data also contain the stock of the domestic-origin labor force for all the countries.

Data for social spending is based on the OECD's Analytical Database (average for 1974-1990). Social expenditure encompass all kinds of social public expenditures, in cash or in kind, including, for instance, old-age transfers, incapacity related benefits, health care, unemployment benefits and other 
social expenditure. Social spending is in PPP 1990 US dollars and is divided by the population of the host country to provide per capita benefits.

\subsection{Quality of Education and Enforcement of Immi- gration Policies}

Since our interest is in the effect of the welfare state on the skill composition of immigrants, controlling for the heterogeneity in the skill (education) measurement is important. Policies controlling for immigration typically ignore differences in the educational quality of source countries. Thus immigrants with the same years of schooling may be treated equally in a points system, although in reality they may vary in their labor market productivity, causing different fiscal burdens. This may introduce a bias in our estimates- in particular for LDC source countries. On one hand, if immigration policies favor higher educational attainment immigrants and one does not control for the quality of education, this would overestimate the effect of skill composition for LDC source countries. On the other hand if high educated immigrants are of poor quality then their productivity would not be that different from the low-skilled ones and they would behave similarly to the low-skilled migrantsin being net recipient rather than contributors to the welfare state, resulting in an underestimate of the effect of welfare generosity on the skill composition. Thus not controlling for educational quality is problematic since we cannot know a priori which way that would bias our results. We control for educational quality of immigrants from all source countries. Hence our migration skill composition is adjusted for varying source country skill quality.

Although Docquier and Marfouk (2006) provide comparable educational 
levels, there is still potentially a very large variation between the quality of educational degrees across countries. To address this potential problem, we adjust all the migration stocks for quality of education using Hanushek and Woessmann (2009) new measures of international differences of cognitive skills.

Hanushek and Woessmann (2009) use international assessments of student achievement such as the First International Mathematics Study (FIMS), the Trends in International Mathematics and Science Study (TIMSS) and the Programme for International Student Assessment (PISA). A total of 12 international student achievement tests (ISATs) were collected. Although varying across the individual assessments, to obtain a common measure of cognitive skills, they rely upon information about the overall distribution of scores on each ISAT to compare national responses. In order to compare performance on the ISATs across tests and over time, they project the performance of different countries on different tests onto a common metric. For that, they develop a common metric both for the level and for the variation of test performance. To make the level of ISATs comparable, they use the only available information on educational performance that is consistently available for comparisons over time: namely, in the form of the National Assessment of Educational Progress (NAEP) from the United States, which has tested the math, science and reading performance of nationally representative samples of 9-, 13-, and 17-year-old US students in an intertemporally comparable way since 1969. The United States is also the only country that has participated in every ISAT.

Their main measure of cognitive skills is a simple average of all standard- 
ized math and science test scores of the ISATs in which a country participated. They use a group of countries to serve as a standardization benchmark for performance variation over time, and choose 13 OECD countries that already had substantial enrollment in secondary education in 1964 and have had relatively stable education systems, which they term the "OECD Standardization Group" (OSG) of countries. Then for each assessment, they calibrate the variance in country mean scores for the subset of the OSG participating to the variance observed on the PISA tests in 2000 (when all OSG countries participated). By combining the adjustments in levels (based on the US NAEP scores) and the adjustment in variances (based on the OSG), they directly calculate standardized scores for all countries on all assessments. Each age group and subject is normalized to the PISA standard of mean 500 and individual standard deviation of 100 across OECD countries (see Appendix B in Hanushek and Woessmann (2009) for full details).

Hanushek and Woessmann (2009) use their schooling quality measure to provide evidence on the robust association between cognitive skills and economic growth. They also find that home-country cognitive-skill levels strongly affect the earnings of immigrants in the US labor market in a difference-in-differences model that compares home-educated to US-educated immigrants from the same country of origin. Thus suggesting that controlling for the quality of schooling is important.

We use their imputed average test scores in math and science for primary through end of secondary school, all years (scaled to PISA scale divided by 100) for all source countries in our sample as our measure of Education Quality (EQ). We interact all the migration stock shares by EQ to adjust 
for varying quality of education across countries. It is important to note two caveats due to the constraints of this quality measure. First, this quality measure does not vary over time since it is an average for various years thus we use the same measure for migration stocks in the 1990s and 2000s. Second, we use the same quality measure for the three educational levels. However, we check for the robustness of our quality of education by using different methods to adjust for quality of education across countries.

Table A1 shows the test scores for math and science scores based on Hanushek and Woessmann (2009). One interesting issue is that education quality varies not only between developed and developing countries but also between developed countries and the EU: the average for the EU (Group A) is 4.939, whilst for Group B (DCs) it is 5.132 and for Group C (LDCs) it is only 3.99. This suggests that there might be a need to control for quality of education not only when considering developing countries but also developed ones.

\section{The Econometric Model}

We specify the source-host pair migration stock with the following equation:

$$
\begin{gathered}
m_{s, h}^{i}=\alpha_{0}^{i}+\alpha_{1}^{i} R_{s, h}+\alpha_{2}^{i} B_{h}+\alpha_{3}^{i} R_{s, h} \cdot B_{h}+\alpha_{4}^{i} X_{s, h}+\alpha_{5}^{i} X_{s, h} \cdot R_{s, h}+\mu_{s, h}^{i} ; \\
\quad i \in\{e, u\} ; \mu_{s, h}^{i}=\theta_{s, h}+\epsilon_{s, h}^{i} \\
R_{s, h}= \begin{cases}0, & \text { if } s, h \text { are in the EU } \\
1, & \text { if } s \text { is not in the EU and } h \text { is in the EU }\end{cases}
\end{gathered}
$$


where $m_{s, h}^{i}$ denotes the stock of migrants of skill level $i$ (comprised of $e$ skilled and $u$ unskilled), who originated from source country $s$ and reside in host country $h$, as a ratio of the stock of all native workers of skill level $i$ in the source country in the year 2000. $R_{s, h}$ is a dummy variable, which equals 0 if the source-host pair exercises free migration, and 1 otherwise. $B_{h}$ denotes the log average benefits per capita in host country $h$ over the period 1974-1990. The remaining control variables are denoted by $X_{s, h}$, which include the stock of unskilled migrants, from source country $s$ in host country $h$, as a ratio of the stock of all native unskilled migrants in the source country $s$ in the year 1990; a similar ratio for skilled migrants; the proportion of unskilled nativeborn workers in the host country $h$ in year 1990; and a similar proportion for the skilled. ${ }^{3}$ We also have interaction terms of all variables with the policy regime dummy variable. The coefficients are depicted by the vectors $\alpha$. The error term is denoted by $\mu_{s, h}^{i}$, which can be divided into two components: a skill-independent effect, $\theta_{s, h}$, and a skill-dependent term, $\epsilon_{s, h}^{i}$.

This simple model estimates the effects of the benefits per capita (and the other control variables) on the migration share, $m_{s, h}^{i}$, for each skill level $i=e, u$. Note that $\theta_{s, h}$ reflects some omitted variables which are skillindependent. In order to avoid the omitted-variable bias which is skillindependent, we define a skill-difference model (a version of difference-indifference model), by subtracting the two equations in (1) and obtain

$\triangle m_{s, h}=\beta_{1} \triangle R_{s, h}+\beta_{2} \triangle B_{h}+\beta_{3} \triangle R_{s, h} \cdot B_{h}+\beta_{4} \triangle X_{s, h}+\beta_{5} \triangle X_{s, h} R_{s, h}+\epsilon_{s, h}$,

\footnotetext{
${ }^{3}$ The last two control variables do not add up to one because we omitted workers with fewer than eight years of schooling.
} 
where $\triangle$ is the skill-difference operator.

The dependent variable, $\triangle m_{s, h}=m_{s, h}^{e}-m_{s, h}^{u}$, can be considered as a measure for the skill composition of migrants in the year 2000. Equation (2) estimates the relative effects of the regressors on $\triangle m_{s, h}$. A positive estimation of a certain coefficient indicates a positive effect on the skill composition measure of the migrants, and vice versa. Note that the effect of welfare state generosity on the skill composition of the migrants under free migration is captured in the above equation by the coefficient $\Delta \beta_{2}$. Therefore, the null hypothesis describing this effect is:

$$
\beta_{2}<0
$$

In addition, the effect of welfare state generosity on the skill composition of migrants in the case of restricted migration is captured by the coefficient $\Delta \beta_{2}+\Delta \beta_{3}$. Therefore the null hypothesis describing this effect is:

$$
\beta_{3}>0
$$

An important statistical feature of the difference-in-difference model is that it eliminates the skill-independent error term, $\theta_{s, h}$. Any variable whose impact on migration is skill-invariant drops out. Furthermore, by including past migration stocks by skill in 1990 as a part of $X_{s, h}$, we are able to account for other invariant effects.

We also control for other factors that are likely to be skill dependent as follows. First, we attempt to control for other immigration policy measures in the host country that might have an effect on the skill composition of immigrants. We use refugees as a share in total immigrants in 1990 in the 
host country based on the United Nations Population Division Statistics. ${ }^{4}$ To capture the effect of family re-unification schemes adopted in host countries we use the stock of past migrants from the source country in the host country in 1990. Both variables are expected to have a negative impact on the migrant skill mix, since both policies attract low-skilled migrants.

Second, since the generosity of the welfare state might be one of the factors influencing immigration and its composition, we need to control for other push-pull factors. One important determinant of migration is the wage differential or the skill differential between source and host countries. We use real GDP per capita (PPP) in 1990, constant US dollars, for both host and source countries in the absence of data on wages in the source countries. We also use average unemployment rates (average for 1990-1995) in both source and host countries. ${ }^{5}$ In addition, to capture better other pull factors which are likely to affect immigration selectivity a battery of controls is used: (i) inequality measures (Gini coefficient) in the source country in $1990{ }^{6}$ (ii) as a proxy for the returns to skill in the host country, the log value of the skilled-unskilled native labor stock ratio in 1990; (iii) instead of (ii), for the host country, the ratio of skilled-unskilled wage differential measured by the ratio of labor compensation per employee in US dollars PPP in 19957 ; and

\footnotetext{
${ }^{4}$ Unfortunately, we were not able to obtain data on the number or share of refugees for source-host pairs. We have also experimented with using the number of refugees and asylum seekers in the host in 1997, and all our results were robust.

${ }^{5}$ Both GDP per capita and unemployment rates are from the World Bank World Development Indicators.

${ }^{6}$ Data on the Gini coefficient are from the UNU-WIDER World Income Inequality Database (WIID) 2008.

${ }^{7}$ Skilled is financial and business services and unskilled is construction. Source OECD
} 
(iv) the difference in unemployment rates between the skilled and unskilled in the host country in $1998 .^{8}$

Additional controls, such as the distance between source-host countries, which might deter unskilled immigrants more than skilled ones, and samelanguage in source-host countries, which might make immigration particularly attractive for unskilled workers are included. We also control for quantity of education using average years of schooling $(+25$ years $)$ in the source country, extracted from the World Bank World Development Indicators, in addition to adjusting for educational quality as mentioned above.

A potential endogeneity problem may arise- in particular between the level of benefits in the host country, $B_{h}$, and the skill composition of the migrants, $\Delta m_{s, h}$, because skilled immigrants can influence the political economic equilibrium level of benefits. One way to address this problem is to use the average level of benefits over a long period before the year 2000, as we indeed do (using 1974-1990 data). Recall that we also control for the past migration stock rate (in 1990). Thus only migration from 1990-2000 is to be explained by the lagged benefit variable, which is completely predetermined.

In addition, we also instrument the lagged level of benefits in the host country, $B_{h}$, using the legal origin in the host country (English, Scandinavian, or French-German) as an instrument. We also instrument the interaction $R_{s, h}$. $B_{h}$ using the interaction between the legal origin and $R$.The legal origin, Stat.

${ }^{8}$ Unemployment rates of the population aged $25-64$ by level of education; skilled is defined as upper secondary and post-secondary non-tertiary education levels 3-4 (ISCED, 1997) and unskilled is defined as pre-primary, primary and lower-secondary education levels 0-2 (ISCED, 1997). Source: Eurostat. 
a century-old construct, was put in place without having the 2000 migration in mind. The legal origin is, however, closely linked to national attitudes towards the generosity of the welfare state, and its institutional setups. It is therefore likely to be strongly correlated with $B_{h}$, yet with little direct relationship to the skill composition of migrants in the year $2000, \Delta m_{s, h}$.

\subsection{Main Findings}

Table 1 presents the OLS estimation results for both DCs and LDCs for our variables of interest. Our first hypothesis relates to the effect of welfare state benefits on the skill composition of immigrants within free-migration regime. This hypothesis is indeed confirmed (the first row) for Group A. The coefficient is negative and significant. That is, the generosity of the welfare state adversely affects the skill composition of migrants in the free-migration regime, capturing the market-based supply-side effect. The inclusion of the returns to skill proxy measured by the skilled-unskilled native labor stocks ratio in the host country in 1990 (column 2), or (column 3) the skilledunskilled wage differential does not have much of an effect on the magnitude or significance of the coefficients of the welfare-state benefits.

Our second hypothesis relates to the considerations of the host country's voters in policy-controlled migration regimes. We have argued that the difference between the effect of fiscal benefits between the controlled and free-

migration regimes should be positive. Indeed, the coefficient is positive and significantly different than that in the free migration regimes (second row) for DCs (Group B). That is, the effect of the generosity of the welfare state on the skill composition of migrants is positively affected by the migration 
policy of the host countries. However the coefficient is not always significant for LDCs (Group C) suggesting our a priori concern about the endogeneity of welfare benefits. Similar results are obtained when using migration stocks that are adjusted for quality of education, i.e. $\Delta m_{s, h} E Q_{s}$ (see Table 2).

Turing to Table 3 which presents the IV estimates, it is important to note that the first stage Cragg-Donald F-statistics show that our instruments are not subject to weak instrument concerns. Indeed, we find evidence for our first hypothesis, i.e. a negative and significant effect of welfare-state benefits on the skill composition of immigrants within a free-migration regime. The generosity of the welfare-state adversely affects the skill composition of migrants in the free-migration regime. As predicted, using the IV, we find the effect of the generosity of the welfare-state on the skill composition of migrants under the policy-controlled migration regime is positive, for both developed (Group B, Column 1) and developing countries (Group C, Column 4). This result also holds after controlling for all the other push-pull factors (Columns 2 and 3 for DCs and Columns 5 and 6 for LDCs).

One important finding is that the effect of the generosity tends to be larger for DCs relative to LDCs. In other words, a generous welfare state leads to a larger positive effect on the skill composition of migrants from DCs under policy-controlled migration relative to that from LDCs. Overall, our results suggest that $1 \%$ increase in welfare-state benefit spending would improve the skill composition of LDCs migrants by around $2.0 \%$ and of DCs migrants by around $3.5 \%$. There are potentially several reasons for the difference of welfare spending on migrant skill composition between LDCs and DCs. First, it could be because policies controlling for immigration typically ignore differ- 
ences in educational quality, thus we correct for low schooling quality, since immigrants with the same years of schooling may vary in their productivity in the labor market, causing different fiscal burdens. Second, it could also be due to the family re-unification and refugee immigration policies adopted by EU countries- distorting the skill composition for LDCs immigrants- which we control for by using imperfect proxies: namely, percentage of refugees in host and total migrant stock from source in host rather than the percentage of refugees in host from source and the stock of family reunion migrants from source in host.

Table 4 presents IV estimates using migration stocks that are adjusted for quality of education. It is clear that our previous results pertaining to the negative effect of the welfare-state benefits on the skill composition of immigrants within the free-migration regime but a positive effect within the restricted-migration regime for both Groups B and C hold after adjusting for the quality of education. However, it is also worth noting that our findings suggest that controlling for quality of education does strengthen the positive effect of the skill composition of LDCs and hardly changes the estimate for DCs, thus narrowing the gap between the effects for LDCs vs. DCs. Thus a $1 \%$ increase in welfare-state benefit spending would improve the skill composition of LDCs migrants by around $2.5 \%$ and of DCs migrants by around $3.4 \%$.

Turning to the other control variables, the variables capturing immigration policies adopted in the EU have negative effects, as expected: the share of refugees in total migrants in the host country in 1990 has a negative, albeit insignificant, effect whilst the total migrant stock from the source country 
in the host country in 1990 has a negative insignificant effect on the skill composition for DC immigrants and a negative significant impact on LDC immigrant skill composition.

Finally, examining the differential effect of returns to skills under the two policy regimes, we find, interestingly, that inequality in the source country has a negative significant effect on the skill mix of migrants from both LDCs and DCs under restrictive migration and a positive effect under free migration. As for the relative returns to skill in the host, the higher the high-low labor ratio, the lower are the returns to skill and the lower are the skill composition of immigrants. However, this effect seems to be significant only for DCs. Indeed, using the wage differential between high- and low- skilled in the host country, which is a better measure of returns to skills, shows that there is a positive relationship between the returns to skill and the skill composition of migrants for both DCs and LDCs under controlled migration, and no differential effect for free migration. Thus overall, the results indicate that even after controlling for returns to skills, the generosity of the welfare state matters for the skill composition of immigrants.

\subsection{Robustness Tests}

We check the robustness of our findings as follows. Our robustness tests are divided into two parts. First, we check the robustness of our results using different methods to adjust for the quality of education. We use relative quality of education in the source country versus the host country and in-

teract that with the migration stocks, i.e. $\Delta m_{s, h} \cdot \frac{E Q_{s}}{E Q_{h}}$ (Table 5). We then adjust only the high-skilled migration stock by interacting with the relative 
source to host quality of education i.e. $m_{s, h}^{e} E Q_{s}$ (Table 6). All our results are robust and the magnitude of the impact of the welfare-state spending on the compositional migration mix is similar to our results in Table 4.

Second, we use different cuts for the skill composition. We examine the difference between high from medium plus low (Table 7 ). Then we observe the difference between high plus medium from low (Table 8). We present the estimates using education quality adjusted migration stocks. The results are perfectly in line with our main findings.

\section{Conclusion}

Welfare generosity is seen by many as a magnet for immigration. Yet, the effect of the welfare state on immigration and its composition depends on whether the adopted migration policy regime is free or controlled. We argue that welfare-state benefits attract unskilled migrants because they contribute to tax revenues less than what they gain from benefits; and this generosity deters skilled immigrants, because they contribute more in taxes than they receive in benefits. In sharp contrast, the effect of an increase in the generosity of the welfare state on the skill composition of migrants is positive, if migration is controlled by policy. Being net contributors to the welfare state, skilled migrants can help finance a more generous welfare-state system. Thus they are preferred by policy makers to unskilled migrants. The present paper analyzes the effect of the generosity of the welfare state on the skill composition of migrants distinguishing, between immigrants from LDCs versus DCs. We examine the effect of a generous the welfare-state (measured 
as per capita social spending) on the skill composition of migrants under free- versus controlled- migration regimes controlling for the role played by returns to skills in both the source and host countries.

We use bilateral data from the year 2000 on $16 \mathrm{EU}$ countries (14 out of the EU-15 together with Norway and Switzerland which benefit from free labor mobility bilateral agreements with the EU), 10 non-EU OECD countries, and 23 LDC countries. The paper utilizes the difference in policy regimes across EU and non-EU states, distinguishing between DCs and LDCs in order to test for key differences between free and policy-restricted migration in terms of the effect of the welfare state on the skill composition of immigrants. We also control for schooling quality, given the potential bias, since immigrants with the same years of schooling may vary in their productivity in the labor market, causing different fiscal burdens. We find evidence in support of our hypothesis that the generosity of the welfare state adversely affects the skillcomposition of migrants under free-migration; but it exerts a more positive effect under a policy-controlled migration regime relative to a free-migration regime even after controlling for the differential returns in skills in source and host countries. Interestingly, these results hold for both DCs and LDCs, but the effect tends to be larger for DCs. However once we adjust for educational quality, the effect of welfare-state generosity on skill composition increases for immigration from LDCs and converges to that experienced by immigration from DCs.

Our findings highlight the importance of controlling for educational quality when studying high skilled migration from LDCs. In addition, it is clear from our analysis that immigration policies favoring high-skilled migrants do 
not take into account educational quality. Our findings also indicate that other immigration policies such as family reunion and asylum seekers, also affect the skill composition of migrants from developing countries.

\section{References}

[1] Blank, Rebecca M. (1988), "The Effect of Welfare and Wage Levels on the Location Decisions of Female-Headed Households", Journal of Urban Economics, 24, 186.

[2] Borjas, George J. (1987), "Self-Selection and the Earnings of Immigrants", American Economic Review, 77(4), 531-553.

[3] Borjas, George J. (1994), "The Economics of Immigration", Journal of Economic Literature, 32(4), 1667.

[4] Borjas, George J. (1999), "Immigration and Welfare Magnets", Journal of Labor Economics 17(4), 607-37.

[5] Breyer, Friedrich and Ben Craig (1997), "Voting on Social Security: Evidence from OECD Countries" European Journal of Political Economy 13, 705-724.

[6] Brucker, Herbert, Gil Epstein, Barry McCormick, Gilles Saint-Paul, Alessandra Venturini, and Klaus Zimmermann (2001), "Managing Migration in the European Welfare State," mimeo, IZA, Bonn, Germany. 
[7] Cohen, Alon, and Assaf Razin, (2009), "Skill Composition of Migration and Welfare State Generosity: Comparing Free and Policy-Controlled Migration Regimes," NBER Working Papers 14738.

[8] Brueckner, Jan K. (2000), "Welfare Reform and the Race to the Bottom: Theory and Evidence", Southern Economic Journal, 66(3), 505.

[9] De Giorgi, Giacomo and Michele Pellizzari (2006), "Welfare Migration in Europe and the Cost of a Harmonized Social Assistance," IZA Discussion Paper No. 2094.

[10] Docquier, Frederic, Oliver Lohest and Abdeslam Marfouk (2006), "What Determines Migrants' Destination Choice?", mimeo.

[11] Docquier, Frederic and Abdeslam Marfouk (2006), "International Migration by Educational Attainment 1990-2000," in Caglar Ozden and Maurice Schiff (eds.), International Migration, Remittances ad the Brain Drain, McMillan and Palgrave: New York.

[12] Enchautegui, Maria E. (1997), "Welfare Payments and Other Determinants of Female Migration," Journal of Labor Economics, 15, 529.

[13] Gelbach, Jonah B. (2004), "The Life-cycle Welfare Migration Hypothesis: Evidence from the 1980 and 1990 Censuses," Journal of Political Economy 112, no. 5, 1091-1130.

[14] Gramlich, Edward M. and Deborah S. Laren (1984), "Migration and Income Redistribution Resposibilities," Journal of Human Resources, $19(4), 489$. 
[15] Hanushek, Eric and Ludger Woessmann (2009), "Do Better Schools Lead to More Growth? Cognitive Skills, Economic Outcomes, and Causation" NBER Working Papers 14738, 14633.

[16] Khoudour-Castéras, David (2004), "The Impact of Bismarck's Social Legislation on German Emigration Before World War I", University of California, Berkley, Unpublished manuscript.

[17] Lee, Ronald and Timothy Miller, (2000) "Immigration, social security, and broader fiscal impacts," American Economic Review 90, 350-354.

[18] Levine, Phillip B. and David J. Zimmerman (1999), "An Empirical Analysis of the Welfare Magnet Debate Using the NLSY", Journal of Population Economics, 12(3), 391.

[19] McKinnish, Terra (2005), "Importing the Poor: Welfare Magnetism and Cross-Border Welfare Migration" Journal of Human Resources, 40(1), 57.

[20] McKinnish, Terra (2007), "Welfare-Induced Migration at State Borders: New Evidence from Micro-Data" Journal of Public Economics, 91, 437.

[21] Meyer, Bruce D. (2000), "Do the Poor Move to Receive Higher Welfare Benefits?," Northwestern University/University of Chicago Joint Center for Poverty Research, no. 58.

[22] Mulligan, Casey B., and Xavier Sala-i-Martin (1999), "Social Security in Theory and Practice (II): Efficiency Theories, Narrative Theories, and Implications for Reform," NBER Working Paper No. W7119 
[23] Peridy, Nicolas (2006), "The European Union and Its New Neighbors: An Estimation of Migration Potentials," Economic Bulletin, 6(2), 1.

[24] Razin, Assaf and Efraim Sadka (2000). Unskilled migration: a burden or a boon for the welfare state. Scandinavian Journal of Economics 102, 463-479.

[25] Razin, Assaf and Efraim Sadka (2004)."Welfare Migration: Is the Net Fiscal Burden a Good Measure of its Economic Impact on the Welfare of the Native-Born Population?" CESifo Economic Studies, 50(4), 709-716.

[26] Razin, Assaf, Efraim Sadka and Phillip Swagel (2002), "Tax Burden and Migration: A Political Theory and Evidence", Journal of Public Economics, 85, 167.

[27] Southwick, Lawrence Jr. (1981), "Public Welfare Programs and Recipient Migration," Growth and Change, 12(4), 22.

[28] Storesletten, K., 2000. Sustaining fiscal policy through immigration. The Journal of Political Economy 108, 300-24.

[29] Walker, James. 1994. "Migration Among Low-income Households: Helping the Witch Doctors Reach Consensus." Unpublished Paper. 
Table 1: OLS Estimates

Dependent Variable: High-Low Difference in Migration Stock Shares in 2000

\begin{tabular}{|c|c|c|c|c|c|c|}
\hline \multirow[b]{2}{*}{ Welfare generosity } & \multicolumn{3}{|c|}{$\begin{array}{c}\text { DCs } \\
\text { (Groups A \& B) }\end{array}$} & \multicolumn{3}{|c|}{$\begin{array}{c}\text { LDCs } \\
\text { (Groups A \& C) }\end{array}$} \\
\hline & & & & & & \\
\hline $\begin{array}{l}\text { benefits per capita (logs) } \\
1974-90 \text { (host) }\end{array}$ & $\begin{array}{l}-0.116 \\
(0.058)^{* *}\end{array}$ & $\begin{array}{l}-0.129 \\
(0.059)^{* *}\end{array}$ & $\begin{array}{l}-0.124 \\
(0.048)^{* *}\end{array}$ & $\begin{array}{l}-0.124 \\
(0.057)^{* *}\end{array}$ & $\begin{array}{l}-0.144 \\
(0.054) * * *\end{array}$ & $\begin{array}{l}-0.153 \\
(0.051) * * *\end{array}$ \\
\hline $\begin{array}{l}\text { benefits per capita (logs) } \\
1974-90 \text { (host) X R }\end{array}$ & $\begin{array}{l}0.120 \\
(0.055) * * \\
\end{array}$ & $\begin{array}{l}0.139 \\
(0.065) * *\end{array}$ & $\begin{array}{l}0.140 \\
(0.056) * *\end{array}$ & $\begin{array}{l}0.104 \\
(0.066)\end{array}$ & $\begin{array}{l}0.104 \\
(0.079) \\
\end{array}$ & $\begin{array}{l}0.116 \\
(0.066)^{*}\end{array}$ \\
\hline \multicolumn{7}{|l|}{ Past migration stocks } \\
\hline $\begin{array}{l}\text { migration stock share in } \\
1990 \text { - low-skilled }\end{array}$ & $\begin{array}{l}-0.716 \\
(0.132) * * *\end{array}$ & $\begin{array}{l}-0.716 \\
(0.127)^{* * *}\end{array}$ & $\begin{array}{l}-0.707 \\
(0.140)^{* * *}\end{array}$ & $\begin{array}{l}-0.609 \\
(0.128)^{* * *}\end{array}$ & $\begin{array}{l}-0.610 \\
(0.128) * * *\end{array}$ & $\begin{array}{l}-0.605 \\
(0.137) * * *\end{array}$ \\
\hline $\begin{array}{l}\text { migration stock share in } \\
1990 \text { - low-skilled X R }\end{array}$ & $\begin{array}{l}1.728 \\
(0.172) * * *\end{array}$ & $\begin{array}{l}1.761 \\
(0.173)^{* * *}\end{array}$ & $\begin{array}{l}1.731 \\
(0.169)^{* * *}\end{array}$ & $\begin{array}{l}0.278 \\
(0.196)\end{array}$ & $\begin{array}{l}0.555 \\
(0.234)^{* *}\end{array}$ & $\begin{array}{l}0.546 \\
(0.226) * *\end{array}$ \\
\hline $\begin{array}{l}\text { migration stock share in } \\
1990 \text { - high-skilled }\end{array}$ & $\begin{array}{l}1.060 \\
(0.149)^{* * *}\end{array}$ & $\begin{array}{l}1.060 \\
(0.144) * * *\end{array}$ & $\begin{array}{l}1.047 \\
(0.155) * * *\end{array}$ & $\begin{array}{l}0.960 \\
(0.145) * * *\end{array}$ & $\begin{array}{l}0.958 \\
(0.146)^{* * *}\end{array}$ & $\begin{array}{l}0.952 \\
(0.153) * * *\end{array}$ \\
\hline $\begin{array}{l}\text { migration stock share in } \\
1990 \text { - high-skilled X R }\end{array}$ & $\begin{array}{l}-0.725 \\
(0.148)^{* * *}\end{array}$ & $\begin{array}{l}-0.726 \\
(0.142) * * *\end{array}$ & $\begin{array}{l}-0.714 \\
(0.151)^{* * *}\end{array}$ & $\begin{array}{l}-0.478 \\
(0.156)^{* * *}\end{array}$ & $\begin{array}{l}-0.623 \\
(0.169) * * *\end{array}$ & $\begin{array}{l}-0.616 \\
(0.173)^{* * *}\end{array}$ \\
\hline \multicolumn{7}{|l|}{ Returns to skills } \\
\hline $\begin{array}{l}\text { high-low labor ratio in } \\
1990 \text { - (host) }\end{array}$ & & $\begin{array}{l}-0.804 \\
(0.297)^{* * *}\end{array}$ & & & $\begin{array}{l}0.215 \\
(0.395)\end{array}$ & \\
\hline $\begin{array}{l}\text { high-low labor ratio in } \\
1990 \text { (host) X F }\end{array}$ & & $\begin{array}{l}0.275 \\
(0.490)\end{array}$ & & & $\begin{array}{l}-0.009 \\
(0.656)\end{array}$ & \\
\hline $\begin{array}{l}\text { high-low wage diff. in } \\
1995 \text { (host) }\end{array}$ & & & $\begin{array}{l}-0.004 \\
(0.003)\end{array}$ & & & $\begin{array}{l}-0.002 \\
(0.003)\end{array}$ \\
\hline $\begin{array}{l}\text { high-low wage diff. in } \\
1995 \text { - (host) X R }\end{array}$ & & & $\begin{array}{l}0.006 \\
(0.003)^{* *}\end{array}$ & & & $\begin{array}{l}0.004 \\
(0.003)^{*}\end{array}$ \\
\hline Gini in 1990 (source) & & $\begin{array}{l}0.352 \\
(0.116) * * *\end{array}$ & $\begin{array}{l}0.388 \\
(0.124) * * *\end{array}$ & & $\begin{array}{l}0.301 \\
(0.119)^{* *}\end{array}$ & $\begin{array}{l}0.304 \\
(0.129) * *\end{array}$ \\
\hline Gini in 1990 (source) X R & & $\begin{array}{l}-0.349 \\
(0.140)^{* *}\end{array}$ & $\begin{array}{l}-0.376 \\
(0.146)^{* *}\end{array}$ & & $\begin{array}{l}-0.274 \\
(0.143)^{*}\end{array}$ & $\begin{array}{l}-0.268 \\
(0.155)^{*}\end{array}$ \\
\hline $\begin{array}{l}\text { high-low unemp. rate diff. } \\
\text { in } 1990 \text { (host) }\end{array}$ & & $\begin{array}{l}0.005 \\
(0.003)^{*}\end{array}$ & $\begin{array}{l}0.001 \\
(0.003)\end{array}$ & & $\begin{array}{l}0.004 \\
(0.003)\end{array}$ & $\begin{array}{l}0.006 \\
(0.003)^{*}\end{array}$ \\
\hline $\begin{array}{l}\text { high-low unemp. rate diff. } \\
\text { in } 1990 \text { - (host) X F }\end{array}$ & & $\begin{array}{l}-0.002 \\
(0.004)\end{array}$ & $\begin{array}{l}-0.004 \\
(0.004)\end{array}$ & & $\begin{array}{l}-0.005 \\
(0.005)\end{array}$ & $\begin{array}{l}-0.008 \\
(0.005)^{*}\end{array}$ \\
\hline Observations & 384 & 384 & 360 & 601 & 570 & 534 \\
\hline R-squared & 0.864 & 0.870 & 0.874 & 0.833 & 0.809 & 0.814 \\
\hline
\end{tabular}

Notes: Robust standard errors in parentheses; * significant at 10\%; ** significant at 5\%; *** significant at $1 \%$. 
Table 2: OLS Estimates Using Migration Stock Adjusted by Educational Quality Dependent Variable: High-Low Difference in Migration Stock (EQ) Shares in 2000

\begin{tabular}{|c|c|c|c|c|c|c|}
\hline \multirow{2}{*}{ Welfare generosity } & \multicolumn{3}{|c|}{$\begin{array}{c}\text { DCs } \\
\text { (Groups A \& B) }\end{array}$} & \multicolumn{3}{|c|}{$\begin{array}{c}\text { LDCs } \\
\text { (Groups A \& C) }\end{array}$} \\
\hline & & & & & & \\
\hline $\begin{array}{l}\text { benefits per capita } \\
\text { (logs) 1974-90 (host) }\end{array}$ & $\begin{array}{l}-0.575 \\
(0.279)^{* *}\end{array}$ & $\begin{array}{l}-0.673 \\
(0.266) * *\end{array}$ & $\begin{array}{l}-0.682 \\
(0.228)^{* * *}\end{array}$ & $\begin{array}{l}-0.581 \\
(0.274)^{* *}\end{array}$ & $\begin{array}{l}-0.697 \\
(0.269)^{* * *}\end{array}$ & $\begin{array}{l}-0.753 \\
(0.250)^{* * *} \\
\end{array}$ \\
\hline $\begin{array}{l}\text { benefits per capita (logs) } \\
1974-90 \text { (host) X R }\end{array}$ & $\begin{array}{l}0.597 \\
(0.275)^{* *}\end{array}$ & $\begin{array}{l}0.694 \\
(0.312) * *\end{array}$ & $\begin{array}{l}0.695 \\
(0.276)^{* *}\end{array}$ & $\begin{array}{l}0.566 \\
(0.305) *\end{array}$ & $\begin{array}{l}0.615 \\
(0.346)^{*}\end{array}$ & $\begin{array}{l}0.601 \\
(0.266)^{* *}\end{array}$ \\
\hline \multicolumn{7}{|l|}{ Past migration stocks } \\
\hline $\begin{array}{l}\text { migration stock (EQ) } \\
\text { share } 1990 \text { - low }\end{array}$ & $\begin{array}{l}-0.694 \\
(0.148)^{* * *}\end{array}$ & $\begin{array}{l}-0.695 \\
(0.143)^{* * *}\end{array}$ & $\begin{array}{l}-0.685 \\
(0.157)^{* * *}\end{array}$ & $\begin{array}{l}-0.593 \\
(0.141)^{* * *}\end{array}$ & $\begin{array}{l}-0.586 \\
(0.138) * * *\end{array}$ & $\begin{array}{l}-0.578 \\
(0.148)^{* * *}\end{array}$ \\
\hline $\begin{array}{l}\text { migration stock (EQ) } \\
\text { share } 1990 \text { - low X R }\end{array}$ & $\begin{array}{l}1.706 \\
(0.175)^{* * *}\end{array}$ & $\begin{array}{l}1.739 \\
(0.168)^{* * *}\end{array}$ & $\begin{array}{l}1.715 \\
(0.171)^{* * *}\end{array}$ & $\begin{array}{l}0.314 \\
(0.208)\end{array}$ & $\begin{array}{l}0.322 \\
(0.211)\end{array}$ & $\begin{array}{l}0.313 \\
(0.207)\end{array}$ \\
\hline $\begin{array}{l}\text { migration stock (EQ) } \\
\text { share } 1990 \text { - high }\end{array}$ & $\begin{array}{l}1.035 \\
(0.166)^{* * *}\end{array}$ & $\begin{array}{l}1.035 \\
(0.162)^{* * *}\end{array}$ & $\begin{array}{l}1.023 \\
(0.173)^{* * *}\end{array}$ & $\begin{array}{l}0.939 \\
(0.159)^{* * *}\end{array}$ & $\begin{array}{l}0.928 \\
(0.156)^{* * *}\end{array}$ & $\begin{array}{l}0.921 \\
(0.165)^{* * *}\end{array}$ \\
\hline $\begin{array}{l}\text { migration stock (EQ) } \\
\text { share 1990- high X R }\end{array}$ & $\begin{array}{l}-0.700 \\
(0.163)^{* * *}\end{array}$ & $\begin{array}{l}-0.705 \\
(0.158)^{* * *}\end{array}$ & $\begin{array}{l}-0.691 \\
(0.168)^{* * *}\end{array}$ & $\begin{array}{l}-0.480 \\
(0.170)^{* * *}\end{array}$ & $\begin{array}{l}-0.474 \\
(0.168)^{* * *}\end{array}$ & $\begin{array}{l}-0.465 \\
(0.174)^{* * *}\end{array}$ \\
\hline \multicolumn{7}{|l|}{ Returns to skills } \\
\hline $\begin{array}{l}\text { high-low labor ratio in } \\
1990 \text { - (host) }\end{array}$ & & $\begin{array}{l}-3.886 \\
(1.356)^{* * *}\end{array}$ & & & $\begin{array}{l}0.760 \\
(1.962)\end{array}$ & \\
\hline $\begin{array}{l}\text { high-low labor ratio in } \\
1990 \text { (host) X F }\end{array}$ & & $\begin{array}{l}1.157 \\
(2.286) \\
\end{array}$ & & & $\begin{array}{l}0.077 \\
(2.783) \\
\end{array}$ & \\
\hline $\begin{array}{l}\text { high-low wage diff. in } \\
1995 \text { - (host) }\end{array}$ & & & $\begin{array}{l}-0.019 \\
(0.012)\end{array}$ & & & $\begin{array}{l}-0.009 \\
(0.012)\end{array}$ \\
\hline $\begin{array}{l}\text { high-low wage diff. in } \\
1995 \text { (host) X R }\end{array}$ & & & $\begin{array}{l}0.028 \\
(0.013)^{* *}\end{array}$ & & & $\begin{array}{l}0.027 \\
(0.014)^{*}\end{array}$ \\
\hline Gini in 1990 (source) & & $\begin{array}{l}1.820 \\
(0.582)^{* * *}\end{array}$ & $\begin{array}{l}1.937 \\
(0.625)^{* * *}\end{array}$ & & $\begin{array}{l}1.622 \\
(0.511)^{* * *}\end{array}$ & $\begin{array}{l}1.909 \\
(0.559) * * *\end{array}$ \\
\hline $\begin{array}{l}\text { Gini in } 1990 \text { (source) } \\
\text { X R }\end{array}$ & & $\begin{array}{l}-1.677 \\
(0.668)^{* *}\end{array}$ & $\begin{array}{l}-1.849 \\
(0.702)^{* * *}\end{array}$ & & $\begin{array}{l}-1.280 \\
(0.581)^{* *}\end{array}$ & $\begin{array}{l}-1.677 \\
(0.608) * * *\end{array}$ \\
\hline $\begin{array}{l}\text { high-low unemp. rate } \\
\text { diff. in } 1990 \text { - (host) }\end{array}$ & & $\begin{array}{l}0.025 \\
(0.011)\end{array}$ & $\begin{array}{l}0.014 \\
(0.014)\end{array}$ & & $\begin{array}{l}0.026 \\
(0.016)\end{array}$ & $\begin{array}{l}0.038 \\
(0.017) * *\end{array}$ \\
\hline $\begin{array}{l}\text { high-low unemp. rate } \\
\text { diff. in } 1990 \text { (host) X F }\end{array}$ & & $\begin{array}{l}-0.010 \\
(0.020)\end{array}$ & $\begin{array}{l}-0.022 \\
(0.021)\end{array}$ & & $\begin{array}{l}-0.026 \\
(0.023)\end{array}$ & $\begin{array}{l}-0.043 \\
(0.022)^{*}\end{array}$ \\
\hline Observations & 384 & 384 & 360 & 569 & 569 & 533 \\
\hline R-squared & 0.861 & 0.868 & 0.871 & 0.827 & 0.832 & 0.836 \\
\hline
\end{tabular}

Notes: All the migration stocks are adjusted for the quality of education in the source country, i.e. $E Q=\Delta m_{s, h} E Q_{s}$; robust standard errors in parentheses; * significant at $10 \%$; ** significant at $5 \%$; *** significant at $1 \%$. 
Table 3: IV Estimates

Dependent Variable: High-Low Difference in Migration Stock Shares in 2000

\begin{tabular}{|c|c|c|c|c|c|c|}
\hline Welfare generosity & \multicolumn{3}{|c|}{$\begin{array}{c}\text { DCs } \\
\text { (Groups A \& B) }\end{array}$} & \multicolumn{3}{|c|}{$\begin{array}{c}\text { LDCs } \\
\text { (Groups A \& C) }\end{array}$} \\
\hline & & & & & & \\
\hline $\begin{array}{l}\text { Fitted benefits per capita } \\
\text { (logs) } 1974-90 \text { (host) }\end{array}$ & $\begin{array}{l}-0.162 \\
(0.079) * *\end{array}$ & $\begin{array}{l}-0.207 \\
(0.092)^{* *}\end{array}$ & $\begin{array}{l}-0.174 \\
(0.074)^{* *}\end{array}$ & $\begin{array}{l}-0.181 \\
(0.081)^{* *}\end{array}$ & $\begin{array}{l}-0.180 \\
(0.090)^{* *}\end{array}$ & $\begin{array}{l}-0.141 \\
(0.073)^{*}\end{array}$ \\
\hline $\begin{array}{l}\text { Fitted benefits per capita } \\
\text { (logs) } 1974-90 \text { (host) X R }\end{array}$ & $\begin{array}{l}0.268 \\
(0.091)^{* * *}\end{array}$ & $\begin{array}{l}0.255 \\
(0.101)^{* *}\end{array}$ & $\begin{array}{l}0.203 \\
(0.080)^{* *}\end{array}$ & $\begin{array}{l}0.201 \\
(0.089)^{* *}\end{array}$ & $\begin{array}{l}0.209 \\
(0.105) * *\end{array}$ & $\begin{array}{l}0.165 \\
(0.085)^{*}\end{array}$ \\
\hline \multicolumn{7}{|l|}{ Past migration skills } \\
\hline $\begin{array}{l}\text { migration stock share in } \\
1990 \text { - low-skilled }\end{array}$ & $\begin{array}{l}-0.709 \\
(0.130)^{* * *}\end{array}$ & $\begin{array}{l}-0.708 \\
(0.128)^{* * *}\end{array}$ & $\begin{array}{l}-0.701 \\
(0.139)^{* * *}\end{array}$ & $\begin{array}{l}-0.591 \\
(0.133)^{* * *}\end{array}$ & $\begin{array}{l}-0.582 \\
(0.134) * * *\end{array}$ & $\begin{array}{l}-0.580 \\
(0.140)^{* * *}\end{array}$ \\
\hline $\begin{array}{l}\text { migration stock share in } \\
1990 \text { - low-skilled X R }\end{array}$ & $\begin{array}{l}1.776 \\
(0.168)^{* * *}\end{array}$ & $\begin{array}{l}1.782 \\
(0.165)^{* * *}\end{array}$ & $\begin{array}{l}1.753 \\
(0.171)^{* * *}\end{array}$ & $\begin{array}{l}0.558 \\
(0.232)^{* *}\end{array}$ & $\begin{array}{l}0.558 \\
(0.234)^{* *}\end{array}$ & $\begin{array}{l}0.556 \\
(0.226)^{* *}\end{array}$ \\
\hline $\begin{array}{l}\text { migration stock share in } \\
1990 \text { - high-skilled }\end{array}$ & $\begin{array}{l}1.053 \\
(0.148)^{* * *}\end{array}$ & $\begin{array}{l}1.050 \\
(0.147)^{* * *}\end{array}$ & $\begin{array}{l}1.042 \\
(0.155)^{* * *}\end{array}$ & $\begin{array}{l}0.944 \\
(0.150)^{* * *}\end{array}$ & $\begin{array}{l}0.932 \\
(0.151)^{* * *}\end{array}$ & $\begin{array}{l}0.932 \\
(0.156)^{* * *}\end{array}$ \\
\hline $\begin{array}{l}\text { migration stock share in } \\
1990 \text { - high-skilled X R }\end{array}$ & $\begin{array}{l}-0.728 \\
(0.149)^{* * *}\end{array}$ & $\begin{array}{l}-0.724 \\
(0.147) * * *\end{array}$ & $\begin{array}{l}-0.715 \\
(0.153)^{* * *}\end{array}$ & $\begin{array}{l}-0.624 \\
(0.168)^{* * *}\end{array}$ & $\begin{array}{l}-0.612 \\
(0.172)^{* * *}\end{array}$ & $\begin{array}{l}-0.613 \\
(0.172)^{* * *}\end{array}$ \\
\hline \multicolumn{7}{|l|}{ Returns to skills } \\
\hline $\begin{array}{l}\text { high-low labor ratio in } \\
1990 \text { - (host) }\end{array}$ & & $\begin{array}{l}-1.072 \\
(0.368)^{* * *}\end{array}$ & & & $\begin{array}{l}0.060 \\
(0.468)\end{array}$ & \\
\hline $\begin{array}{l}\text { high-low labor ratio in } \\
1990 \text { (host ) X F }\end{array}$ & & $\begin{array}{l}0.671 \\
(0.540)\end{array}$ & & & $\begin{array}{l}0.523 \\
(0.706)\end{array}$ & \\
\hline $\begin{array}{l}\text { high-low wage diff. in } \\
1995 \text { (host) }\end{array}$ & & & $\begin{array}{l}-0.003 \\
(0.002)\end{array}$ & & & $\begin{array}{l}-0.002 \\
(0.003)\end{array}$ \\
\hline $\begin{array}{l}\text { high-low wage diff. in } \\
1995 \text { - (host) X R }\end{array}$ & & & $\begin{array}{l}0.006 \\
(0.003)^{* *}\end{array}$ & & & $\begin{array}{l}0.006 \\
(0.003)^{*}\end{array}$ \\
\hline Gini in 1990 (source) & & $\begin{array}{l}0.330 \\
(0.118)^{* * *}\end{array}$ & $\begin{array}{l}0.349 \\
(0.127)^{* * *}\end{array}$ & & $\begin{array}{l}0.310 \\
(0.120)^{* * *}\end{array}$ & $\begin{array}{l}0.312 \\
(0.128)^{* *}\end{array}$ \\
\hline Gini in 1990 (source) X R & & $\begin{array}{l}-0.353 \\
(0.143)^{* *}\end{array}$ & $\begin{array}{l}-0.397 \\
(0.148)^{* * *}\end{array}$ & & $\begin{array}{l}-0.280 \\
(0.144)^{*}\end{array}$ & $\begin{array}{l}-0.273 \\
(0.154)^{*}\end{array}$ \\
\hline $\begin{array}{l}\text { high-low unemp. rate } \\
\text { diff. } 1990 \text { (host) }\end{array}$ & & $\begin{array}{l}0.007 \\
(0.003)^{* *}\end{array}$ & $\begin{array}{l}0.003 \\
(0.002)\end{array}$ & & $\begin{array}{l}0.005 \\
(0.003)\end{array}$ & $\begin{array}{l}0.009 \\
(0.003)^{* *}\end{array}$ \\
\hline $\begin{array}{l}\text { high-low unemp. rate } \\
\text { diff. } 1990 \text { - (host) X F }\end{array}$ & & $\begin{array}{l}-0.004 \\
(0.005)\end{array}$ & $\begin{array}{l}-0.005 \\
(0.004)\end{array}$ & & $\begin{array}{l}-0.008 \\
(0.006)\end{array}$ & $\begin{array}{l}-0.008 \\
(0.005)^{*}\end{array}$ \\
\hline \multicolumn{7}{|l|}{ Immigration policies } \\
\hline $\begin{array}{l}\text { Total migrant stock } \\
\text { in } 1990\end{array}$ & $\begin{array}{l}-0.001 \\
(0.001)\end{array}$ & $\begin{array}{l}-0.001 \\
(0.001)\end{array}$ & $\begin{array}{l}-0.001 \\
(0.001)\end{array}$ & $\begin{array}{l}-0.002 \\
(0.001)^{* * *}\end{array}$ & $\begin{array}{l}-0.003 \\
(0.001)^{* * *}\end{array}$ & $\begin{array}{l}-0.003 \\
(0.001)^{* *}\end{array}$ \\
\hline Share of refugees in 1990 & $\begin{array}{l}-0.002 \\
(0.003)\end{array}$ & $\begin{array}{l}0.001 \\
(0.004)\end{array}$ & $\begin{array}{l}-0.002 \\
(0.004)\end{array}$ & $\begin{array}{l}-0.002 \\
(0.003)\end{array}$ & $\begin{array}{l}-0.003 \\
(0.003) \\
\end{array}$ & $\begin{array}{l}-0.001 \\
(0.003)\end{array}$ \\
\hline Cragg-Donald F- statistics & 52.00 & 59.04 & 63.13 & 86.02 & 98.46 & 99.07 \\
\hline Observations & 384 & 384 & 360 & 538 & 538 & 504 \\
\hline R-squared & 0.865 & 0.871 & 0.875 & 0.811 & 0.815 & 0.821 \\
\hline
\end{tabular}

Notes: Robust standard errors in parentheses; * significant at 10\%; ** significant at 5\%; *** significant at $1 \%$. 
Table 4: IV Estimates Using Migration Stock Adjusted by Educational Quality Dependent Variable: High-Low Difference in Migration Stock (EQ) Shares in 2000

\begin{tabular}{|c|c|c|c|c|c|c|}
\hline \multirow[b]{2}{*}{ Welfare generosity } & \multicolumn{3}{|c|}{$\begin{array}{c}\text { DCs } \\
\text { (Groups A \& B) }\end{array}$} & \multicolumn{3}{|c|}{$\begin{array}{c}\text { LDCs } \\
\text { (Groups A \& C) }\end{array}$} \\
\hline & & & & & & \\
\hline $\begin{array}{l}\text { Fitted benefits per capita } \\
\text { (logs) } 1974-90 \text { (host) }\end{array}$ & $\begin{array}{l}-0.797 \\
(0.375)^{* *}\end{array}$ & $\begin{array}{l}-1.022 \\
(0.444)^{* *}\end{array}$ & $\begin{array}{l}-0.864 \\
(0.357)^{* *}\end{array}$ & $\begin{array}{l}-0.854 \\
(0.372)^{* *}\end{array}$ & $\begin{array}{l}-0.896 \\
(0.428)^{* *}\end{array}$ & $\begin{array}{l}-0.882 \\
(0.354)^{* *}\end{array}$ \\
\hline $\begin{array}{l}\text { Fitted benefits per capita } \\
\text { (logs) } 1974-90 \text { (host) X R }\end{array}$ & $\begin{array}{l}1.316 \\
(0.441)^{* * *}\end{array}$ & $\begin{array}{l}1.262 \\
(0.486) * * *\end{array}$ & $\begin{array}{l}1.000 \\
(0.387)^{* *}\end{array}$ & $\begin{array}{l}1.032 \\
(0.409)^{* *}\end{array}$ & $\begin{array}{l}1.058 \\
(0.474)^{* *}\end{array}$ & $\begin{array}{l}0.916 \\
(0.384)^{* *}\end{array}$ \\
\hline \multicolumn{7}{|l|}{ Past migration stocks } \\
\hline $\begin{array}{l}\text { migration stock (EQ) } \\
\text { share } 1990 \text { - low }\end{array}$ & $\begin{array}{l}-0.686 \\
(0.147) * * *\end{array}$ & $\begin{array}{l}-0.685 \\
(0.145)^{* * *}\end{array}$ & $\begin{array}{l}-0.677 \\
(0.156)^{* * *}\end{array}$ & $\begin{array}{l}-0.598 \\
(0.143)^{* * *}\end{array}$ & $\begin{array}{l}-0.588 \\
(0.143)^{* * *}\end{array}$ & $\begin{array}{l}-0.588 \\
(0.151)^{* * *}\end{array}$ \\
\hline $\begin{array}{l}\text { migration stock (EQ) } \\
\text { share } 1990 \text { - low X R }\end{array}$ & $\begin{array}{l}1.749 \\
(0.172)^{* * *}\end{array}$ & $\begin{array}{l}1.763 \\
(0.171)^{* * *}\end{array}$ & $\begin{array}{l}1.734 \\
(0.177)^{* * *}\end{array}$ & $\begin{array}{l}0.563 \\
(0.210)^{* * *}\end{array}$ & $\begin{array}{l}0.566 \\
(0.213) * * *\end{array}$ & $\begin{array}{l}0.559 \\
(0.213)^{* * *}\end{array}$ \\
\hline $\begin{array}{l}\text { migration stock (EQ) } \\
\text { share } 1990 \text { - high }\end{array}$ & $\begin{array}{l}1.027 \\
(0.165)^{* * *}\end{array}$ & $\begin{array}{l}1.024 \\
(0.164)^{* * *}\end{array}$ & $\begin{array}{l}1.014 \\
(0.173)^{* * *}\end{array}$ & $\begin{array}{l}0.941 \\
(0.162)^{* * *}\end{array}$ & $\begin{array}{l}0.927 \\
(0.163) * * *\end{array}$ & $\begin{array}{l}0.926 \\
(0.168) * * *\end{array}$ \\
\hline $\begin{array}{l}\text { migration stock (EQ) } \\
\text { share } 1990 \text { - high X R }\end{array}$ & $\begin{array}{l}-0.701 \\
(0.164)^{* * *}\end{array}$ & $\begin{array}{l}-0.698 \\
(0.163)^{* * *}\end{array}$ & $\begin{array}{l}-0.689 \\
(0.170)^{* * *}\end{array}$ & $\begin{array}{l}-0.635 \\
(0.171)^{* * *}\end{array}$ & $\begin{array}{l}-0.623 \\
(0.175)^{* * *}\end{array}$ & $\begin{array}{l}-0.619 \\
(0.178)^{* * *}\end{array}$ \\
\hline \multicolumn{7}{|l|}{ Returns to skills } \\
\hline $\begin{array}{l}\text { high-low labor ratio in } \\
1990 \text { - (host) }\end{array}$ & & $\begin{array}{l}-5.303 \\
(1.767)^{* * *}\end{array}$ & & & $\begin{array}{l}0.040 \\
(1.798) \\
\end{array}$ & \\
\hline $\begin{array}{l}\text { high-low labor ratio in } \\
1990 \text { (host) X F }\end{array}$ & & $\begin{array}{l}3.374 \\
(2.604)\end{array}$ & & & $\begin{array}{l}1.903 \\
(3.007)\end{array}$ & \\
\hline $\begin{array}{l}\text { high-low wage diff. in } \\
1995 \text { (host) }\end{array}$ & & & $\begin{array}{l}-0.015 \\
(0.011) \\
\end{array}$ & & & $\begin{array}{l}-0.014 \\
(0.012)\end{array}$ \\
\hline $\begin{array}{l}\text { high-low wage diff. in } \\
1995 \text { - (host) X R }\end{array}$ & & & $\begin{array}{l}0.031 \\
(0.014)^{* *}\end{array}$ & & & $\begin{array}{l}0.025 \\
(0.015)^{*}\end{array}$ \\
\hline Gini in 1990 (source) & & $\begin{array}{l}1.694 \\
(0.600)^{* * *}\end{array}$ & $\begin{array}{l}1.792 \\
(0.645)^{* * *}\end{array}$ & & $\begin{array}{l}1.612 \\
(0.602)^{* * *}\end{array}$ & $\begin{array}{l}1.887 \\
(0.636) * * *\end{array}$ \\
\hline $\begin{array}{l}\text { Gini in } 1990 \text { (source) } \\
\text { X R }\end{array}$ & & $\begin{array}{l}-1.787 \\
(0.723)^{* *}\end{array}$ & $\begin{array}{l}-1.999 \\
(0.751)^{* * *}\end{array}$ & & $\begin{array}{l}-1.542 \\
(0.713)^{* *}\end{array}$ & $\begin{array}{l}-1.822 \\
(0.732)^{* *}\end{array}$ \\
\hline $\begin{array}{l}\text { high-low unemp. rate } \\
\text { diff. } 1990 \text { (host) }\end{array}$ & & $\begin{array}{l}0.035 \\
(0.015)^{* *}\end{array}$ & $\begin{array}{l}0.009 \\
(0.013)\end{array}$ & & $\begin{array}{l}0.020 \\
(0.013)\end{array}$ & $\begin{array}{l}0.025 \\
(0.014)^{*}\end{array}$ \\
\hline $\begin{array}{l}\text { high-low unemp. rate } \\
\text { diff. } 1990 \text { - (host) X F }\end{array}$ & & $\begin{array}{l}-0.023 \\
(0.024) \\
\end{array}$ & $\begin{array}{l}-0.023 \\
(0.022) \\
\end{array}$ & & $\begin{array}{l}-0.034 \\
(0.026) \\
\end{array}$ & $\begin{array}{l}-0.037 \\
(0.022)^{*}\end{array}$ \\
\hline \multicolumn{7}{|l|}{ Immigration policies } \\
\hline Total migrant stock in 1990 & $\begin{array}{l}-0.005 \\
(0.004)\end{array}$ & $\begin{array}{l}-0.004 \\
(0.003)\end{array}$ & $\begin{array}{l}-0.005 \\
(0.004)\end{array}$ & $\begin{array}{l}-0.010 \\
(0.004)^{* * *}\end{array}$ & $\begin{array}{l}-0.011 \\
(0.004)^{* * *}\end{array}$ & $\begin{array}{l}-0.011 \\
(0.004)^{* *}\end{array}$ \\
\hline Share of refugees in 1990 & $\begin{array}{l}-0.012 \\
(0.016)\end{array}$ & $\begin{array}{l}-0.004 \\
(0.018) \\
\end{array}$ & $\begin{array}{l}-0.011 \\
(0.018) \\
\end{array}$ & $\begin{array}{l}-0.010 \\
(0.013) \\
\end{array}$ & $\begin{array}{l}-0.014 \\
(0.014) \\
\end{array}$ & $\begin{array}{l}-0.013 \\
(0.015) \\
\end{array}$ \\
\hline Cragg-Donald F- statistics & 51.89 & 59.10 & 63.11 & 85.90 & 99.55 & 94.69 \\
\hline Observations & 384 & 384 & 360 & 538 & 538 & 504 \\
\hline R-squared & 0.861 & 0.868 & 0.872 & 0.810 & 0.814 & 0.817 \\
\hline
\end{tabular}

Notes: All the migration stocks are adjusted for the quality of education in the source country, i.e. $E Q=\Delta m_{s, h} E Q_{s}$; robust standard errors in parentheses; * significant at 10\%; ** significant at 5\%; *** significant at $1 \%$. 
Table 5: Robustness Test: Using Migration Stock Adjusted by Relative Educational Quality; IV Estimates Dependent Variable: High-Low Difference in Migration Stock (REQ) Shares in 2000

\begin{tabular}{|c|c|c|c|c|c|c|}
\hline \multirow[b]{2}{*}{ Welfare generosity } & \multicolumn{3}{|c|}{$\begin{array}{c}\text { DCs } \\
\text { (Groups A \& B) } \\
\end{array}$} & \multicolumn{3}{|c|}{$\begin{array}{c}\text { LDCs } \\
\text { (Groups A \& C) }\end{array}$} \\
\hline & & & & & & \\
\hline $\begin{array}{l}\text { Fitted benefits per capita } \\
\text { (logs) } 1974-90 \text { (host) }\end{array}$ & $\begin{array}{l}-0.169 \\
(0.078) * *\end{array}$ & $\begin{array}{l}-0.210 \\
(0.091)^{* *}\end{array}$ & $\begin{array}{l}-0.176 \\
(0.074)^{* *}\end{array}$ & $\begin{array}{l}-0.175 \\
(0.077)^{* *}\end{array}$ & $\begin{array}{l}-0.193 \\
(0.089) * *\end{array}$ & $\begin{array}{l}-0.166 \\
(0.073)^{* *}\end{array}$ \\
\hline $\begin{array}{l}\text { Fitted benefits per capita } \\
\text { (logs) } 1974-90 \text { (host) X R }\end{array}$ & $\begin{array}{l}0.268 \\
(0.089)^{* * *}\end{array}$ & $\begin{array}{l}0.260 \\
(0.099)^{* * *}\end{array}$ & $\begin{array}{l}0.206 \\
(0.079)^{* * *}\end{array}$ & $\begin{array}{l}0.209 \\
(0.085)^{* *}\end{array}$ & $\begin{array}{l}0.235 \\
(0.105)^{* *}\end{array}$ & $\begin{array}{l}0.189 \\
(0.085)^{* *}\end{array}$ \\
\hline \multicolumn{7}{|l|}{ Past migration stocks } \\
\hline $\begin{array}{l}\text { migration stock (REQ) } \\
\text { share } 1990 \text { - low }\end{array}$ & $\begin{array}{l}-0.685 \\
(0.151)^{* * *}\end{array}$ & $\begin{array}{l}-0.685 \\
(0.149)^{* * *}\end{array}$ & $\begin{array}{l}-0.678 \\
(0.160)^{* * *}\end{array}$ & $\begin{array}{l}-0.601 \\
(0.146)^{* * *}\end{array}$ & $\begin{array}{l}-0.575 \\
(0.144)^{* * *}\end{array}$ & $\begin{array}{l}-0.574 \\
(0.151)^{* * *}\end{array}$ \\
\hline $\begin{array}{l}\text { migration stock (REQ) } \\
\text { share } 1990 \text { - low X R }\end{array}$ & $\begin{array}{l}1.744 \\
(0.171)^{* * *}\end{array}$ & $\begin{array}{l}1.754 \\
(0.169)^{* * *}\end{array}$ & $\begin{array}{l}1.724 \\
(0.175)^{* * *}\end{array}$ & $\begin{array}{l}0.549 \\
(0.216)^{* *}\end{array}$ & $\begin{array}{l}0.305 \\
(0.210) \\
\end{array}$ & $\begin{array}{l}0.304 \\
(0.207) \\
\end{array}$ \\
\hline $\begin{array}{l}\text { migration stock (REQ) } \\
\text { share } 1990 \text { - high }\end{array}$ & $\begin{array}{l}1.022 \\
(0.169) * * *\end{array}$ & $\begin{array}{l}1.022 \\
(0.168)^{* * *}\end{array}$ & $\begin{array}{l}1.013 \\
(0.176)^{* * *}\end{array}$ & $\begin{array}{l}0.939 \\
(0.165)^{* * *}\end{array}$ & $\begin{array}{l}0.914 \\
(0.164)^{* * *}\end{array}$ & $\begin{array}{l}0.914 \\
(0.168)^{* * *}\end{array}$ \\
\hline $\begin{array}{l}\text { migration stock (REQ) } \\
\text { share } 1990 \text { - high X R }\end{array}$ & $\begin{array}{l}-0.698 \\
(0.167)^{* * *}\end{array}$ & $\begin{array}{l}-0.692 \\
(0.165)^{* * *}\end{array}$ & $\begin{array}{l}-0.682 \\
(0.172)^{* * *}\end{array}$ & $\begin{array}{l}-0.628 \\
(0.175)^{* * *}\end{array}$ & $\begin{array}{l}-0.459 \\
(0.175)^{* * *}\end{array}$ & $\begin{array}{l}-0.460 \\
(0.178)^{* * *}\end{array}$ \\
\hline \multicolumn{7}{|l|}{ Returns to skills } \\
\hline $\begin{array}{l}\text { high-low labor ratio in } \\
1990 \text { - (host) }\end{array}$ & & $\begin{array}{l}-1.102 \\
(0.356)^{* * *}\end{array}$ & & & $\begin{array}{l}-0.019 \\
(0.416)\end{array}$ & \\
\hline $\begin{array}{l}\text { high-low labor ratio in } \\
1990 \text { (host) X F }\end{array}$ & & $\begin{array}{l}0.707 \\
(0.534)\end{array}$ & & & $\begin{array}{l}0.524 \\
(0.612)\end{array}$ & \\
\hline $\begin{array}{l}\text { high-low wage diff. in } \\
1995 \text { (host) }\end{array}$ & & & $\begin{array}{l}-0.003 \\
(0.002)\end{array}$ & & & $\begin{array}{l}-0.002 \\
(0.003)\end{array}$ \\
\hline $\begin{array}{l}\text { high-low wage diff. in } \\
1995 \text { - (host) X R }\end{array}$ & & & $\begin{array}{l}0.007 \\
(0.003)^{* *}\end{array}$ & & & $\begin{array}{l}0.006 \\
(0.003)^{*}\end{array}$ \\
\hline Gini in 1990 (source) & & $\begin{array}{l}0.372 \\
(0.119)^{* * *}\end{array}$ & $\begin{array}{l}0.398 \\
(0.127)^{* * *}\end{array}$ & & $\begin{array}{l}0.360 \\
(0.119)^{* * *}\end{array}$ & $\begin{array}{l}0.367 \\
(0.128)^{* * *}\end{array}$ \\
\hline Gini in 1990 (source) X R & & $\begin{array}{l}-0.345 \\
(0.142)^{* *}\end{array}$ & $\begin{array}{l}-0.384 \\
(0.148)^{* * *}\end{array}$ & & $\begin{array}{l}-0.297 \\
(0.140)^{* *}\end{array}$ & $\begin{array}{l}-0.295 \\
(0.150)^{* *}\end{array}$ \\
\hline $\begin{array}{l}\text { high-low unemp. rate diff. } \\
\text { in } 1990 \text { (host) }\end{array}$ & & $\begin{array}{l}0.007 \\
(0.003)^{* *}\end{array}$ & $\begin{array}{l}0.002 \\
(0.002)\end{array}$ & & $\begin{array}{l}0.006 \\
(0.003)^{*}\end{array}$ & $\begin{array}{l}0.009 \\
(0.003)^{* * *}\end{array}$ \\
\hline $\begin{array}{l}\text { high-low unemp. rate diff. } \\
\text { in } 1990 \text { - (host) X F }\end{array}$ & & $\begin{array}{l}-0.005 \\
(0.005)\end{array}$ & $\begin{array}{l}-0.005 \\
(0.004)\end{array}$ & & $\begin{array}{l}-0.009 \\
(0.005)\end{array}$ & $\begin{array}{l}-0.009 \\
(0.005)^{*}\end{array}$ \\
\hline \multicolumn{7}{|l|}{ Immigration policies } \\
\hline Total migrant stock in 1990 & $\begin{array}{l}-0.001 \\
(0.001)\end{array}$ & $\begin{array}{l}-0.001 \\
(0.001)\end{array}$ & $\begin{array}{l}-0.001 \\
(0.001)\end{array}$ & $\begin{array}{l}-0.002 \\
(0.001)^{* *}\end{array}$ & $\begin{array}{l}-0.002 \\
(0.001)^{* * *}\end{array}$ & $\begin{array}{l}-0.002 \\
(0.001)^{* *}\end{array}$ \\
\hline Share of refugees in 1990 & $\begin{array}{l}-0.002 \\
(0.003)\end{array}$ & $\begin{array}{l}-0.001 \\
(0.004)\end{array}$ & $\begin{array}{l}-0.002 \\
(0.004)\end{array}$ & $\begin{array}{l}-0.002 \\
(0.003)\end{array}$ & $\begin{array}{l}-0.002 \\
(0.003)\end{array}$ & $\begin{array}{l}-0.000 \\
(0.003)\end{array}$ \\
\hline Observations & 384 & 384 & 360 & 538 & 569 & 533 \\
\hline R-squared & 0.863 & 0.867 & 0.871 & 0.805 & 0.830 & 0.835 \\
\hline
\end{tabular}

Notes: All the migration stocks are adjusted for the quality of education, i.e. $R E Q=\Delta m_{s, h .}\left(E Q_{s} / E Q_{h}\right)$; robust standard errors in parentheses; * significant at $10 \%$; ** significant at $5 \%$; *** significant at $1 \%$. 
Table 6: Using High-Skilled Educational Quality Adjusted Migration Stock; IV Estimates Dependent Variable: High (HEQ)-Low Difference in Migration Stock Shares in 2000

\begin{tabular}{|c|c|c|c|c|c|c|}
\hline \multirow[b]{2}{*}{ Welfare generosity } & \multicolumn{3}{|c|}{$\begin{array}{c}\text { DCs } \\
\text { (Groups A \& B) }\end{array}$} & \multicolumn{3}{|c|}{$\begin{array}{c}\text { LDCs } \\
\text { (Groups A \& C) }\end{array}$} \\
\hline & & & & & & \\
\hline $\begin{array}{l}\text { Fitted benefits per capita } \\
\text { (logs) } 1974-90 \text { (host) }\end{array}$ & $\begin{array}{l}-0.158 \\
(0.076)^{* *}\end{array}$ & $\begin{array}{l}-0.206 \\
(0.089) * *\end{array}$ & $\begin{array}{l}-0.171 \\
(0.072)^{* *}\end{array}$ & $\begin{array}{l}-0.179 \\
(0.075)^{* *}\end{array}$ & $\begin{array}{l}-0.161 \\
(0.078)^{* *}\end{array}$ & $\begin{array}{l}-0.135 \\
(0.068) * *\end{array}$ \\
\hline $\begin{array}{l}\text { Fitted benefits per capita } \\
\text { (logs) } 1974-90 \text { (host) X R }\end{array}$ & $\begin{array}{l}0.265 \\
(0.089)^{* * *}\end{array}$ & $\begin{array}{l}0.253 \\
(0.098) * *\end{array}$ & $\begin{array}{l}0.200 \\
(0.078)^{* *}\end{array}$ & $\begin{array}{l}0.191 \\
(0.080) * *\end{array}$ & $\begin{array}{l}0.184 \\
(0.092)^{* *}\end{array}$ & $\begin{array}{l}0.159 \\
(0.074)^{* *}\end{array}$ \\
\hline \multicolumn{7}{|l|}{ Past migration stocks } \\
\hline $\begin{array}{l}\text { migration stock } \\
\text { share } 1990 \text { - low }\end{array}$ & $\begin{array}{l}-0.706 \\
(0.128)^{* * *}\end{array}$ & $\begin{array}{l}-0.706 \\
(0.125)^{* * *}\end{array}$ & $\begin{array}{l}-0.697 \\
(0.136)^{* * *}\end{array}$ & $\begin{array}{l}-0.620 \\
(0.123)^{* * *}\end{array}$ & $\begin{array}{l}-0.614 \\
(0.123)^{* * *}\end{array}$ & $\begin{array}{l}-0.610 \\
(0.130)^{* * *}\end{array}$ \\
\hline $\begin{array}{l}\text { migration stock } \\
\text { share } 1990 \text { - low X R }\end{array}$ & $\begin{array}{l}1.796 \\
(0.165) * * *\end{array}$ & $\begin{array}{l}1.804 \\
(0.161)^{* * *}\end{array}$ & $\begin{array}{l}1.773 \\
(0.167)^{* * * *}\end{array}$ & $\begin{array}{l}0.440 \\
(0.158) * * *\end{array}$ & $\begin{array}{l}0.443 \\
(0.160)^{* * *}\end{array}$ & $\begin{array}{l}0.442 \\
(0.154)^{* * *}\end{array}$ \\
\hline $\begin{array}{l}\text { migration stock (HEQ) } \\
\text { share } 1990 \text { - high }\end{array}$ & $\begin{array}{l}1.049 \\
(0.144)^{* * *}\end{array}$ & $\begin{array}{l}1.047 \\
(0.142) * * *\end{array}$ & $\begin{array}{l}1.036 \\
(0.150)^{* * *}\end{array}$ & $\begin{array}{l}0.967 \\
(0.140) * * *\end{array}$ & $\begin{array}{l}0.959 \\
(0.141)^{* * *}\end{array}$ & $\begin{array}{l}0.955 \\
(0.145)^{* * *}\end{array}$ \\
\hline $\begin{array}{l}\text { migration stock (HEQ) } \\
\text { share } 1990 \text { - high X R }\end{array}$ & $\begin{array}{l}-0.711 \\
(0.144)^{* * *}\end{array}$ & $\begin{array}{l}-0.708 \\
(0.141)^{* * *}\end{array}$ & $\begin{array}{l}-0.698 \\
(0.148)^{* * *}\end{array}$ & $\begin{array}{l}-0.684 \\
(0.150)^{* * *}\end{array}$ & $\begin{array}{l}-0.679 \\
(0.152)^{* * *}\end{array}$ & $\begin{array}{l}-0.677 \\
(0.153)^{* * *}\end{array}$ \\
\hline \multicolumn{7}{|l|}{ Returns to skills } \\
\hline $\begin{array}{l}\text { high-low labor ratio in } \\
1990 \text { - (host) }\end{array}$ & & $\begin{array}{l}-1.119 \\
(0.369) * * *\end{array}$ & & & $\begin{array}{l}0.236 \\
(0.341)\end{array}$ & \\
\hline $\begin{array}{l}\text { high-low labor ratio in } \\
1990 \text { (host ) X F }\end{array}$ & & $\begin{array}{l}0.655 \\
(0.533)\end{array}$ & & & $\begin{array}{l}0.151 \\
(0.592)\end{array}$ & \\
\hline $\begin{array}{l}\text { high-low wage diff. in } \\
1995 \text { (host) }\end{array}$ & & & $\begin{array}{l}-0.003 \\
(0.002)\end{array}$ & & & $\begin{array}{l}-0.003 \\
(0.003)\end{array}$ \\
\hline $\begin{array}{l}\text { high-low wage diff. in } \\
1995 \text { - (host) X R }\end{array}$ & & & $\begin{array}{l}0.006 \\
(0.003)^{* *}\end{array}$ & & & $\begin{array}{l}0.004 \\
(0.003)\end{array}$ \\
\hline Gini in 1990 (source) & & $\begin{array}{l}0.333 \\
(0.118)^{* * *}\end{array}$ & $\begin{array}{l}0.352 \\
(0.127)^{* * *}\end{array}$ & & $\begin{array}{l}0.328 \\
(0.117)^{* * *}\end{array}$ & $\begin{array}{l}0.113 \\
(0.126)^{* * *}\end{array}$ \\
\hline Gini in 1990 (source) X R & & $\begin{array}{l}-0.342 \\
(0.333)^{* *}\end{array}$ & $\begin{array}{l}-0.384 \\
(0.352)^{* *}\end{array}$ & & $\begin{array}{l}-0.310 \\
(0.328)^{* *}\end{array}$ & $\begin{array}{l}-0.305 \\
(0.150)^{* *}\end{array}$ \\
\hline $\begin{array}{l}\text { high-low unemp. rate diff. } \\
\text { in } 1990 \text { (host) }\end{array}$ & & $\begin{array}{l}0.007 \\
(0.003)^{* *}\end{array}$ & $\begin{array}{l}0.002 \\
(0.003)\end{array}$ & & $\begin{array}{l}0.001 \\
(0.002)\end{array}$ & $\begin{array}{l}0.004 \\
(0.003)^{* *}\end{array}$ \\
\hline $\begin{array}{l}\text { high-low unemp. rate diff. } \\
\text { in } 1990 \text { - (host) X F }\end{array}$ & & $\begin{array}{l}-0.005 \\
(0.005)\end{array}$ & $\begin{array}{l}-0.005 \\
(0.004)\end{array}$ & & $\begin{array}{l}-0.005 \\
(0.005)\end{array}$ & $\begin{array}{l}-0.007 \\
(0.004)\end{array}$ \\
\hline \multicolumn{7}{|l|}{ Immigration policies } \\
\hline Total migrant stock in 1990 & $\begin{array}{l}-0.001 \\
(0.001)\end{array}$ & $\begin{array}{l}-0.001 \\
(0.001)\end{array}$ & $\begin{array}{l}-0.001 \\
(0.001)\end{array}$ & $\begin{array}{l}-0.002 \\
(0.001) * * *\end{array}$ & $\begin{array}{l}-0.022 \\
(0.001)^{* * * *}\end{array}$ & $\begin{array}{l}-0.002 \\
(0.001) * *\end{array}$ \\
\hline Share of refugees in 1990 & $\begin{array}{l}-0.002 \\
(0.003)\end{array}$ & $\begin{array}{l}-0.001 \\
(0.004)\end{array}$ & $\begin{array}{l}-0.002 \\
(0.004)\end{array}$ & $\begin{array}{l}-0.001 \\
(0.002)\end{array}$ & $\begin{array}{l}-0.003 \\
(0.003)\end{array}$ & $\begin{array}{l}-0.002 \\
(0.003)\end{array}$ \\
\hline Observations & 384 & 384 & 360 & 538 & 538 & 504 \\
\hline R-squared & 0.875 & 0.881 & 0.885 & 0.820 & 0.826 & 0.831 \\
\hline
\end{tabular}

Notes: High-skilled migration stocks are weighted for the relative quality of education, i.e. $H E Q=m_{s, h .}^{e} E Q_{s}$; robust standard errors in parentheses; * significant at $10 \%$; ** significant at $5 \%$; *** significant at $1 \%$. 
Table 7: Robustness Test: Using Migration Stock Weighted by Educational Quality; IV Estimates Dependent Variable: High - Medium and Low Difference in Migration Stock (EQ) Shares in 2000

\begin{tabular}{|c|c|c|c|c|}
\hline \multirow{2}{*}{ Welfare generosity } & \multicolumn{2}{|c|}{$\begin{array}{c}\text { DCs } \\
\text { (Groups A and B) }\end{array}$} & \multicolumn{2}{|c|}{$\begin{array}{c}\text { LDCs } \\
\text { (Groups A and C) }\end{array}$} \\
\hline & & & & \\
\hline $\begin{array}{l}\text { Fitted benefits per capita } \\
\text { (logs) 1974-90 (host) }\end{array}$ & $\begin{array}{l}-0.790 \\
(0.307)^{* *}\end{array}$ & $\begin{array}{l}-0.866 \\
(0.313)^{* * *}\end{array}$ & $\begin{array}{l}-0.472 \\
(0.290)\end{array}$ & $\begin{array}{l}-0.769 \\
(0.305)^{* *}\end{array}$ \\
\hline $\begin{array}{l}\text { Fitted benefits per capita } \\
\text { (logs) } 1974-90 \text { (host) X R }\end{array}$ & $\begin{array}{l}0.893 \\
(0.377)^{* *}\end{array}$ & $\begin{array}{l}1.177 \\
(0.421)^{* * *}\end{array}$ & $\begin{array}{l}0.567 \\
(0.342)^{*}\end{array}$ & $\begin{array}{l}0.768 \\
(0.388)^{* *}\end{array}$ \\
\hline \multicolumn{5}{|l|}{ Past migration stocks } \\
\hline $\begin{array}{l}\text { migration stock (EQ) } \\
\text { share } 1990 \text { - low }\end{array}$ & $\begin{array}{l}-1.004 \\
(0.104)^{* * *}\end{array}$ & $\begin{array}{l}-0.996 \\
(0.100)^{* * *}\end{array}$ & $\begin{array}{l}-0.924 \\
(0.108)^{* * *}\end{array}$ & $\begin{array}{l}-0.909 \\
(0.107)^{* * *}\end{array}$ \\
\hline $\begin{array}{l}\text { migration stock (EQ) } \\
\text { share } 1990 \text { - low X R }\end{array}$ & $\begin{array}{l}1.490 \\
(0.346)^{* * *}\end{array}$ & $\begin{array}{l}1.495 \\
(0.339)^{* * *}\end{array}$ & $\begin{array}{l}0.809 \\
(0.308)^{* * *}\end{array}$ & $\begin{array}{l}0.814 \\
(0.304)^{* * *}\end{array}$ \\
\hline $\begin{array}{l}\text { migration stock (EQ) } \\
\text { share } 1990 \text { - high }\end{array}$ & $\begin{array}{l}-0.582 \\
(0.189)^{* * *}\end{array}$ & $\begin{array}{l}-0.567 \\
(0.187)^{* * *}\end{array}$ & $\begin{array}{l}-0.580 \\
(0.189)^{* * *}\end{array}$ & $\begin{array}{l}-0.564 \\
(0.186)^{* * *}\end{array}$ \\
\hline $\begin{array}{l}\text { migration stock (EQ) } \\
\text { share } 1990 \text { - high X R }\end{array}$ & $\begin{array}{l}1.224 \\
(1.222)\end{array}$ & $\begin{array}{l}1.207 \\
(1.187)\end{array}$ & $\begin{array}{l}-0.458 \\
(0.273)^{*}\end{array}$ & $\begin{array}{l}-0.462 \\
(0.270)^{*}\end{array}$ \\
\hline $\begin{array}{l}\text { migration stock (EQ) } \\
\text { share } 1990 \text { - medium }\end{array}$ & $\begin{array}{l}1.056 \\
(0.223)^{* * *}\end{array}$ & $\begin{array}{l}1.030 \\
(0.222)^{* * *}\end{array}$ & $\begin{array}{l}0.975 \\
(0.216)^{* * *}\end{array}$ & $\begin{array}{l}0.939 \\
(0.216)^{* * *}\end{array}$ \\
\hline $\begin{array}{l}\text { migration stock (EQ) } \\
\text { share } 1990 \text { - medium X R }\end{array}$ & $\begin{array}{l}-0.882 \\
(0.241)^{* * *}\end{array}$ & $\begin{array}{l}-0.858 \\
(0.237)^{* * *}\end{array}$ & $\begin{array}{l}-0.616 \\
(0.243)^{* *}\end{array}$ & $\begin{array}{l}-0.586 \\
(0.244)^{* *}\end{array}$ \\
\hline \multicolumn{5}{|l|}{ Returns to skills } \\
\hline $\begin{array}{l}\text { high- medium \& low labor } \\
\text { ratio in } 1990 \text { (host) }\end{array}$ & & $\begin{array}{l}-4.801 \\
(4.454)\end{array}$ & & $\begin{array}{l}7.413 \\
(4.475)^{*}\end{array}$ \\
\hline $\begin{array}{l}\text { high- medium \& low labor } \\
\text { ratio in } 1990 \text { (host ) X F }\end{array}$ & & $\begin{array}{l}20.743 \\
(8.908)^{* *}\end{array}$ & & $\begin{array}{l}12.134 \\
(11.026)\end{array}$ \\
\hline Gini in 1990 (source) & & $\begin{array}{l}0.954 \\
(0.717)\end{array}$ & & $\begin{array}{l}0.868 \\
(0.690)\end{array}$ \\
\hline Gini in 1990 (source) X R & & $\begin{array}{l}-0.394 \\
(0.939)\end{array}$ & & $\begin{array}{l}-0.735 \\
(0.814)\end{array}$ \\
\hline \multicolumn{5}{|l|}{ Immiaration policies } \\
\hline $\begin{array}{l}\text { Total migrant stock } \\
\text { in } 1990\end{array}$ & $\begin{array}{l}0.001 \\
(0.003)\end{array}$ & $\begin{array}{l}0.000 \\
(0.003)\end{array}$ & $\begin{array}{l}-0.005 \\
(0.004)\end{array}$ & $\begin{array}{l}-0.006 \\
(0.004)\end{array}$ \\
\hline Share of refugees in 1990 & $\begin{array}{l}0.003 \\
(0.016)\end{array}$ & $\begin{array}{l}-0.006 \\
(0.013)\end{array}$ & $\begin{array}{l}-0.008 \\
(0.011)\end{array}$ & $\begin{array}{l}-0.010 \\
(0.011)\end{array}$ \\
\hline Observations & 384 & 384 & 538 & 538 \\
\hline R-squared & 0.956 & 0.956 & 0.938 & 0.937 \\
\hline
\end{tabular}

Notes: All the migration stocks are adjusted for the quality of education, i.e. migration stock *EQ; robust standard errors in parentheses; * significant at $10 \%$; ** significant at $5 \%$; *** significant at $1 \%$. 
Table 8: Robustness Test: Using Migration Stock Weighted by Educational Quality; IV Estimates Dependent Variable: High + Medium \& Low Difference in Migration Stock (EQ) Shares in 2000

\begin{tabular}{|c|c|c|c|c|}
\hline \multirow[b]{2}{*}{ Welfare generosity } & \multicolumn{2}{|c|}{$\begin{array}{c}\text { DCs } \\
\text { (Groups A \& B) }\end{array}$} & \multicolumn{2}{|c|}{$\begin{array}{c}\text { LDCs } \\
\text { (Groups A \& C) }\end{array}$} \\
\hline & & & & \\
\hline $\begin{array}{l}\text { Fitted benefits per capita } \\
\text { (logs) 1974-90 (host) }\end{array}$ & $\begin{array}{l}-1.020 \\
(0.600)^{*}\end{array}$ & $\begin{array}{l}-0.879 \\
(0.444) * *\end{array}$ & $\begin{array}{l}-1.107 \\
(0.528)^{* *}\end{array}$ & $\begin{array}{l}-0.797 \\
(0.432)^{*}\end{array}$ \\
\hline $\begin{array}{l}\text { Fitted benefits per capita } \\
\text { (logs) 1974-90 (host) X R }\end{array}$ & $\begin{array}{l}1.885 \\
(0.567)^{* * * *} \\
\end{array}$ & $\begin{array}{l}1.124 \\
(0.521)^{* *}\end{array}$ & $\begin{array}{l}1.428 \\
(0.536)^{* * *}\end{array}$ & $\begin{array}{l}0.859 \\
(0.480)^{*}\end{array}$ \\
\hline \multicolumn{5}{|l|}{ Past migration stocks } \\
\hline $\begin{array}{l}\text { migration stock (EQ) } \\
\text { share } 1990 \text { - low }\end{array}$ & $\begin{array}{l}-0.465 \\
(0.077) * * *\end{array}$ & $\begin{array}{l}-0.471 \\
(0.078) * * *\end{array}$ & $\begin{array}{l}-0.396 \\
(0.081)^{* * *}\end{array}$ & $\begin{array}{l}-0.399 \\
(0.081)^{* * *}\end{array}$ \\
\hline $\begin{array}{l}\text { migration stock (EQ) } \\
\text { share } 1990 \text { - low X R }\end{array}$ & $\begin{array}{l}1.595 \\
(0.530)^{* * *}\end{array}$ & $\begin{array}{l}1.644 \\
(0.561)^{* * *}\end{array}$ & $\begin{array}{l}0.310 \\
(0.207)\end{array}$ & $\begin{array}{l}0.331 \\
(0.211)\end{array}$ \\
\hline $\begin{array}{l}\text { migration stock (EQ) } \\
\text { share } 1990 \text { - high }\end{array}$ & $\begin{array}{l}0.773 \\
(0.266) * * *\end{array}$ & $\begin{array}{l}0.782 \\
(0.263) * * *\end{array}$ & $\begin{array}{l}0.725 \\
(0.263) * * *\end{array}$ & $\begin{array}{l}0.716 \\
(0.253) * * *\end{array}$ \\
\hline $\begin{array}{l}\text { migration stock (EQ) } \\
\text { share } 1990 \text { - high X R }\end{array}$ & $\begin{array}{l}-0.416 \\
(0.274)\end{array}$ & $\begin{array}{l}-0.401 \\
(0.271)\end{array}$ & $\begin{array}{l}-0.478 \\
(0.268)^{*}\end{array}$ & $\begin{array}{l}-0.475 \\
(0.258)^{*}\end{array}$ \\
\hline $\begin{array}{l}\text { migration stock (EQ) } \\
\text { share } 1990 \text { - medium }\end{array}$ & $\begin{array}{l}0.876 \\
(0.222)^{* * *}\end{array}$ & $\begin{array}{l}0.876 \\
(0.219) * * *\end{array}$ & $\begin{array}{l}0.862 \\
(0.221)^{* * *}\end{array}$ & $\begin{array}{l}0.873 \\
(0.213)^{* * *}\end{array}$ \\
\hline $\begin{array}{l}\text { migration stock (EQ) } \\
\text { share } 1990 \text { - medium X R }\end{array}$ & $\begin{array}{l}0.227 \\
(1.450) \\
\end{array}$ & $\begin{array}{l}-0.006 \\
(1.545) \\
\end{array}$ & $\begin{array}{l}0.459 \\
(0.459) \\
\end{array}$ & $\begin{array}{l}0.466 \\
(0.447) \\
\end{array}$ \\
\hline \multicolumn{5}{|l|}{ Returns to skills } \\
\hline $\begin{array}{l}\text { high- medium \& low labor } \\
\text { ratio in } 1990 \text { - (host) }\end{array}$ & & $\begin{array}{l}-1.391 \\
(0.802)^{*}\end{array}$ & & $\begin{array}{l}1.478 \\
(0.813)^{*}\end{array}$ \\
\hline $\begin{array}{l}\text { high- medium \& low labor } \\
\text { ratio in } 1990 \text { (host) X F }\end{array}$ & & $\begin{array}{l}-0.464 \\
(1.590)\end{array}$ & & $\begin{array}{l}-1.586 \\
(1.557)\end{array}$ \\
\hline Gini in 1990 (source) & & $\begin{array}{l}2.864 \\
(0.941)^{* * * *}\end{array}$ & & $\begin{array}{l}2.721 \\
(0.891)^{* * *}\end{array}$ \\
\hline Gini in 1990 (source) X R & & $\begin{array}{l}-3.483 \\
(1.175) * * *\end{array}$ & & $\begin{array}{l}-2.740 \\
(1.068) * *\end{array}$ \\
\hline \multicolumn{5}{|l|}{ Immigration policies } \\
\hline $\begin{array}{l}\text { Total migrant stock } \\
\text { in } 1990\end{array}$ & $\begin{array}{l}-0.007 \\
(0.003)^{* * *}\end{array}$ & $\begin{array}{l}-0.007 \\
(0.003)^{* *}\end{array}$ & $\begin{array}{l}-0.012 \\
(0.003)^{* * *}\end{array}$ & $\begin{array}{l}-0.012 \\
(0.003)^{* * *}\end{array}$ \\
\hline \multirow[t]{2}{*}{ Share of refugees in 1990} & -0.020 & -0.017 & -0.017 & -0.022 \\
\hline & $(0.020)$ & $(0.021)$ & $(0.017)$ & $(0.016)$ \\
\hline Observations & 384 & 384 & 538 & 538 \\
\hline R-squared & 0.964 & 0.966 & 0.957 & 0.958 \\
\hline
\end{tabular}

Note: All the migration stocks are adjusted for the quality of education, i.e. migration stock *EQ; robust standard errors in parentheses; * significant at $10 \%$; ** significant at $5 \%$; *** significant at $1 \%$. 
Appendix 1:

Table A1: Test Scores

\begin{tabular}{|c|c|c|c|c|c|}
\hline \multicolumn{2}{|c|}{ Group A } & \multicolumn{2}{|c|}{ Group B } & \multicolumn{2}{|c|}{ Group C } \\
\hline Country & EQ & Country & EQ & Country & EQ \\
\hline Austria & 5.089 & Australia & 5.094 & Argentina & 3.920 \\
\hline Belgium & 5.041 & Canada & 5.038 & Brazil & 3.638 \\
\hline Switzerland & 5.142 & Hong Kong & 5.195 & Chile & 4.049 \\
\hline Denmark & 4.962 & Israel & 4.686 & China & 4.939 \\
\hline Spain & 4.829 & Japan & 5.310 & Colombia & 4.152 \\
\hline Finland & 5.126 & Korea, Rep. & 5.338 & Egypt & 4.030 \\
\hline France & 5.040 & New Zealand & 4.978 & Indonesia & 3.880 \\
\hline $\begin{array}{l}\text { United } \\
\text { Kingdom }\end{array}$ & 4.950 & Singapore & 5.330 & India & 4.281 \\
\hline Germany & 4.956 & $\begin{array}{l}\text { Taiwan } \\
\text { (Chinese Taipei) }\end{array}$ & 5.452 & Iran & 4.219 \\
\hline Greece & 4.608 & United States & 4.903 & Jordan & 4.264 \\
\hline Ireland & 4.995 & & & Lebanon & 3.950 \\
\hline Italy & 4.758 & & & Morocco & 3.327 \\
\hline Netherlands & 5.115 & & & Mexico & 3.998 \\
\hline Norway & 4.830 & & & Malaysia & 4.838 \\
\hline Portugal & 4.564 & & & Nigeria & 4.154 \\
\hline Sweden & 5.013 & & & Peru & 3.125 \\
\hline & & & & Philippines & 3.647 \\
\hline & & & & Thailand & 4.565 \\
\hline & & & & Tunisia & 3.795 \\
\hline & & & & Turkey & 4.128 \\
\hline & & & & South Africa & 3.089 \\
\hline $\begin{array}{l}\text { Group } \\
\text { Averages }\end{array}$ & 4.939 & & 5.132 & & 3.999 \\
\hline
\end{tabular}

Notes: EQ = average test score in math and science, primary through end of secondary school, all years (scaled to PISA scale divided by 100). 